\title{
THE MOUNT FAIRPLAY IGNEOUS COMPLEX
}

Rainer J. Newberry

Preliminary Interpretive Report 2020-1

This publication is PRELIMINARY in nature and meant to allow rapid release of field observations or initial interpretations of geology or analytical data. It has undergone limited peer review, but does not necessarily conform to DGGS editorial standards. Interpretations or conclusions contained in this publication are subject to change.

2020

STATE OF ALASKA DEPARTMENT OF NATURAL RESOURCES DIVISION OF GEOLOGICAL \& GEOPHYSICAL SURVEYS
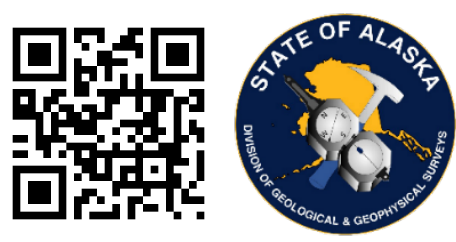


\section{STATE OF ALASKA}

Mike Dunleavy, Governor

\section{DEPARTMENT OF NATURAL RESOURCES}

Corri A. Feige, Commissioner

\section{DIVISION OF GEOLOGICAL \& GEOPHYSICAL SURVEYS}

Steve Masterman, State Geologist \& Director

Publications produced by the Division of Geological \& Geophysical Surveys are available to download from the DGGS website (dggs.alaska.gov). Publications on hard-copy or digital media can be examined or purchased in the Fairbanks office:

\section{Alaska Division of Geological \& Geophysical Surveys (DGGS) \\ 3354 College Road | Fairbanks, Alaska 99709-3707 \\ Phone: 907.451.5010 | Fax 907.451.5050 \\ dggspubs@alaska.gov $\mid$ dggs.alaska.gov}

\section{DGGS publications are also available at:}

Alaska State Library, Historical

Collections \& Talking Book Center

395 Whittier Street

Juneau, Alaska 99801

Alaska Resource Library and

Information Services (ARLIS)

3150 C Street, Suite 100

Anchorage, Alaska 99503

\section{Suggested citation:}

Newberry, RJ., 2020, The Mount Fairplay igneous complex: Alaska Division of Geological \&

Geophysical Surveys Preliminary Interpretive Report 2020-1, 32 p.

http://doi.org/10.14509/30463
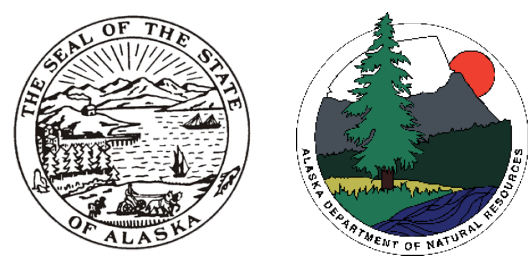


\section{THE MOUNT FAIRPLAY IGNEOUS COMPLEX}

Rainer J. Newberry ${ }^{1}$

\section{ABSTRACT}

The Mount Fairplay igneous complex is an approximately 24-square-kilometer (9-square-mile) intrusive body located in eastern Interior Alaska. The complex is latest Cretaceous (ca. $67 \mathrm{Ma}$ ) in age and consists of two recognized intrusive suites or groups: (1) an alkalic group comprising quartz-poor lithologies (monzonite, syenite, alkali-feldspar syenite) and (2) a slightly younger, sub-alkalic group comprising quartzrich lithologies (granite and quartz monzonite). Ilmenite and magnetite compositions of the alkalic rocks indicate magmatic oxidation states in the vicinity of the fayalite-quartz-magnetite (FQM) buffer; in contrast, data for the quartz-rich suite indicates conditions much more oxidized than the FQM buffer. Both groups typically contain diopsidic clinopyroxene, biotite, and amphibole, and the most mafic of the alkalic group contains olivine or iddingsite. Microprobe studies show that amphibole, biotite, and feldspar compositions vary according to both primary magmatic and secondary, post-magmatic processes or alteration.

Some parts of the complex, particularly the alkali-feldspar syenite, are enriched in rare earth elements (REE) uranium (U), niobium ( $\mathrm{Nb}$ ), and thorium (Th). Magmatic apatite at Mount Fairplay has low-REE cores and REE-enriched rims; however, in hydrothermally altered samples, magmatic apatite is replaced by REE-depleted apatite, which is accompanied by secondary REE minerals including monazite, allanite, huttonite, and cheralite. Titanite, the bulk of which appears to be secondary, contains significant $\mathrm{Nb}(0.2-5$ percent $\mathrm{Nb}_{2} \mathrm{O}_{5}$ ) and light REEs (0.2-3 percent total LREE oxide). The alkali-feldspar syenite has the highest $\mathrm{REE}$ and $\mathrm{Nb}$ concentrations, both in titanite and in whole-rock analyses. The alkalic rocks at Mount Fairplay also contain elevated fluorine (F) in concentrations well above those typical for igneous titanite. Other secondary minerals, including amphibole, biotite, and scapolite, contain elevated concentrations of chlorine $(\mathrm{Cl})$ and probably also $\mathrm{F}$, and these halogen enrichments are apparently restricted to the alkalic group of rocks and absent from the quartz-rich group. One sample of alkali-feldspar syenite also contains fluorite. Together, these features indicate that hydrothermal fluids containing relatively high $\mathrm{Cl}$ and fluorine $(\mathrm{F})$ concentrations affected parts of the Mount Fairplay complex.

\section{INTRODUCTION}

The Mount Fairplay igneous complex is an approximately 24-square-kilometer (9-square-mile) body along, and east, of the Taylor Highway, in the Tanacross C-3 Quadrangle (fig. 1). It has been previously mapped (Foster, 1967; Kerin, 1976) but there are no available chemical analyses. Due to its alkalic nature, it was investigated for its REE potential. This study is based on 37 major-, minor-, and trace-element analyses of plutonic rocks from the complex and immediate vicinity, examination of 24 thin sections, and EDS microprobe analyses from 10 of these. The results of this study show that REE enrichment and F-rich hydrothermal alteration are present locally, mainly within the alkali-feldspar syenite. However, the mapped volume of this unit and the REE-enrichment measured do not appear to be economically significant.

\footnotetext{
${ }^{1}$ Department of Geology \& Geophysics, University of Alaska, P.O. Box 755780, Fairbanks, AK 99775-5780
} 


\section{MAJOR-AND TRACE-ELEMENT CHARACTERISTICS}

Based on CIPW normative classification (fig. 2), the Mount Fairplay complex consists of two major rock groups: (1) those containing normative feldspathoids or little to no quartz, and (2) those with significant quartz. The former group, the alkalic group, comprises monzonite, syenite, and rare alkali-feldspar syenite compositions; the latter, sub-alkalic group, comprises quartz monzonite and granite. Based on the distribution of rock types and previous mapping, the central 40 percent of the exposed complex contains significant quartz (fig. 1), and the quartz-poor rocks occur north, east, and south of the quartz-rich ones (fig. 1). Steeply dipping faults are inferred along the west and north contacts, due to abrupt changes in the aeromagnetic pattern (Emond and others, 2015) and to an alignment of drainages and (or) topographic saddles. Monzonite (having low abundance of quartz and sub-equal plagioclase and alkali feldspar) is restricted to the northern end of the complex; alkali-feldspar syenite is of very restricted occurrence on the south side and accounts for about 1 percent of the complex (fig. 1).

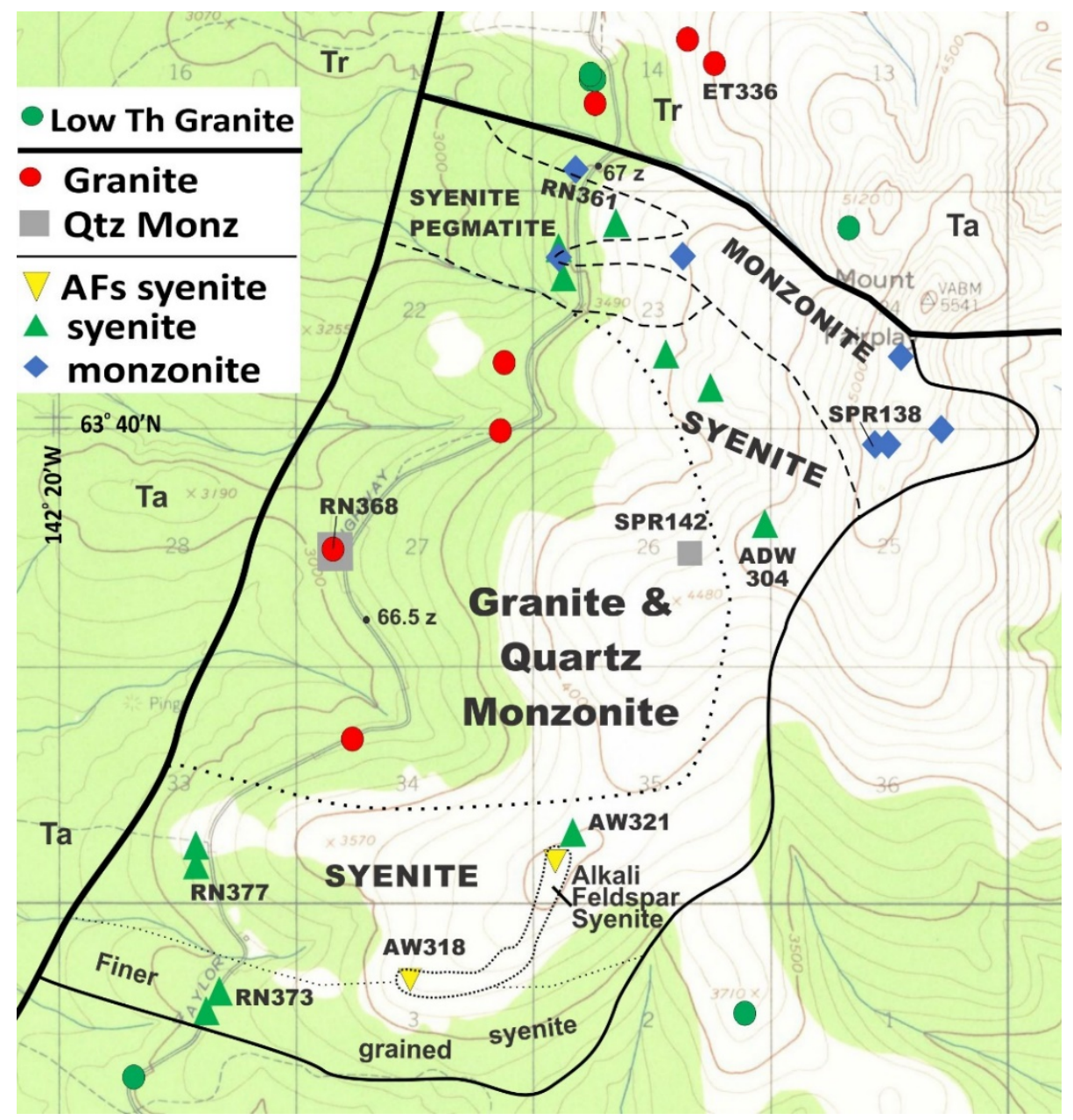

Figure 1. Generalized geologic map of the Mount Fairplay igneous complex. Symbols = major-minor oxide sample (Wypych and others, 2019); those labeled with sample numbers have thin sections used for microprobe analysis in this study. Small black dots show locations of zircon U-Pb analyses and ages in million years (Ma). Thick black lines $=$ inferred faults. $\mathrm{Ta}=\mathrm{Tertiary}$ andesite; $\mathrm{Tr}=\mathrm{Tertiary}$ rhyolite; QtzMonz = Quart Monzonite; AFs = Alkali Feldspar. The squares are 1-mile by 1-mile sections on the topographic map. 
The compositional differences between the alkalic and sub-alkalic rocks of Mount Fairplay are illustrated on the alkali versus silica diagram of Currie (1973; fig. 3). Further, the alkalic rocks are not strongly alkali-rich, as indicated by their compositions plotting in the 'alkali basalt family' group and not the syeniteor nephelinite-family groups. Carbonatites (and many plutonic-associated REE deposits) are associated with rocks of the miaskitic family (Heinrich, 1980; Salvi and Williams-Jones, 2005).

The quartz-rich and quartz-poor rocks both contain anomalous Th ( $\geq 30 \mathrm{ppm}$ ) relative to the other granitic rocks in the region (fig. $4 \mathrm{~A}$ ), but the quartz-poor rocks display a fractionation-related increase not displayed by the quartz-rich ones. Similarly, the rocks are enriched in $U$ and as a whole display cerium (Ce) enrichment, but the Ce enrichment factor (largest/smallest concentrations) in the quartz-poor rocks is 2.4, and that of $U$ and Th is approximately 10 (fig. 4B). In other words, the quartz-rich and quartz-poor rocks of the Mount Fairplay complex appear to be related, but the quartz-rich rocks do not display the same REE enrichment. Based on their co-varying rubidium $(\mathrm{Rb})$ and strontium $(\mathrm{Sr})$ concentrations (fig. 5), both types do display fractionation trends, but fractionation of the quartz-rich rocks doesn't seem to have enriched them in other elements besides $\mathrm{Rb}$.

Based on finding examples of chilled contacts, Kerin (1976) indicated that the body of quartz-rich rocks (his quartz monzonite unit) is younger than the quartz-poor rocks. Radiometric ages (fig. 1) also seemingly indicate that the granite and quartz monzonite part of the Mount Fairplay complex is slightly younger $(66.5 \pm 1.1 \mathrm{Ma})$ than the syenite $(67 \pm 1.5 \mathrm{Ma}$; both ages are SHRIMP U-Pb zircon ages [Wilson and others, 2015]), although the ages are within error of each other. The combination of alkalic and quartz-rich rocks is not unique to Mount Fairplay, however. World-wide, this combination is fairly common and generally considered to be due to crustal contamination of alkaline magma (Salvi and Williams-Jones, 2005). This hypothetical contamination not only increased the silica content of the contaminated magma, but also potentially changed other variables; for example, oxidation state.

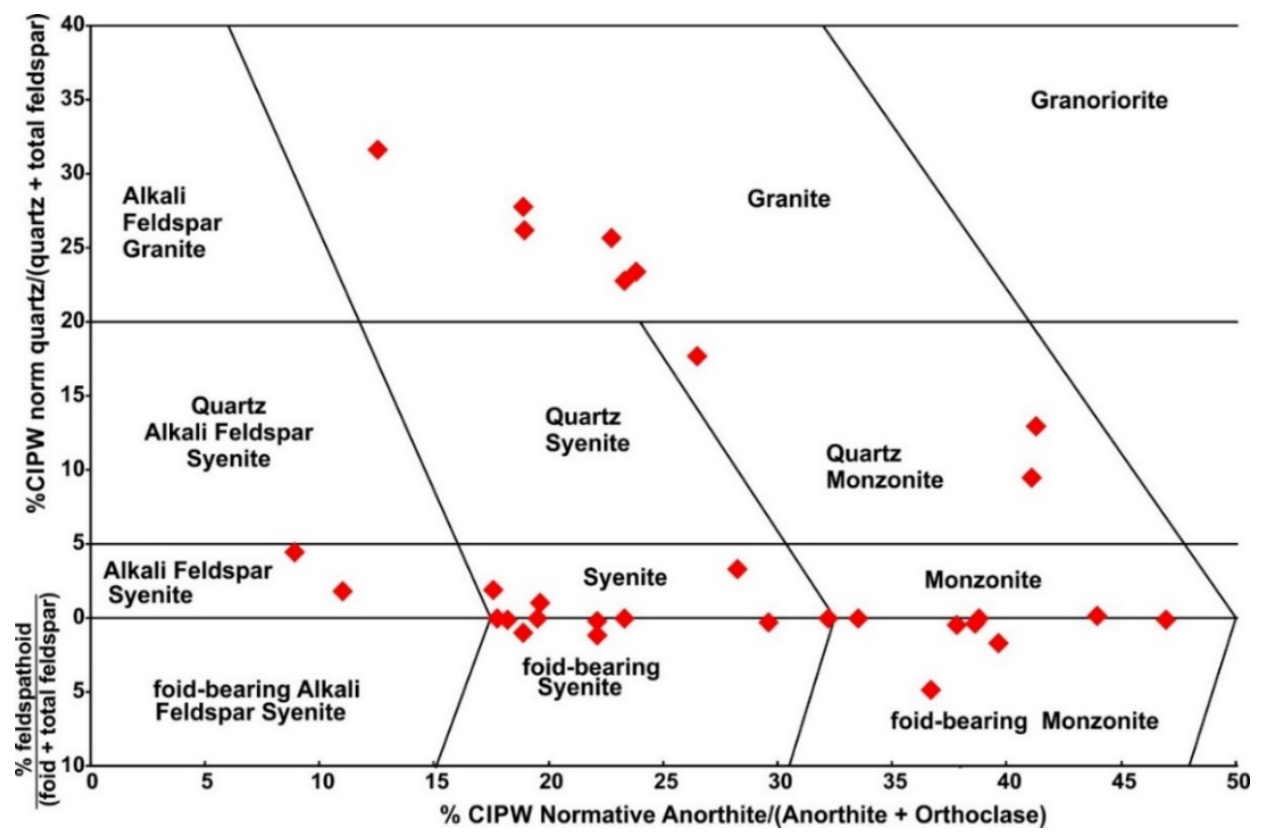

Figure 2. Classification of rocks from the Mount Fairplay complex, based on normative calculated mineral abundances. Wholerock geochemical data from Wypych and others (2019). Diagram is modified from Streckeisen and Le Maitre (1979). 


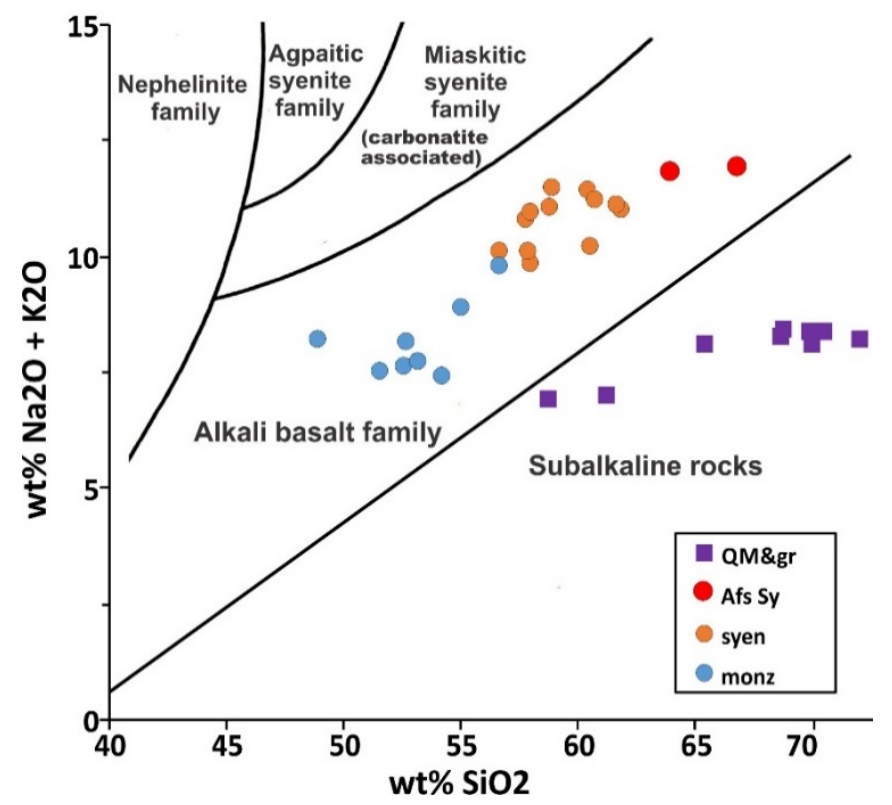

Figure 3. Alkali vs. silica diagram for Mount Fairplay rocks with fields from Currie (1973). Whole-rock geochemical data from Wypych and others (2019).
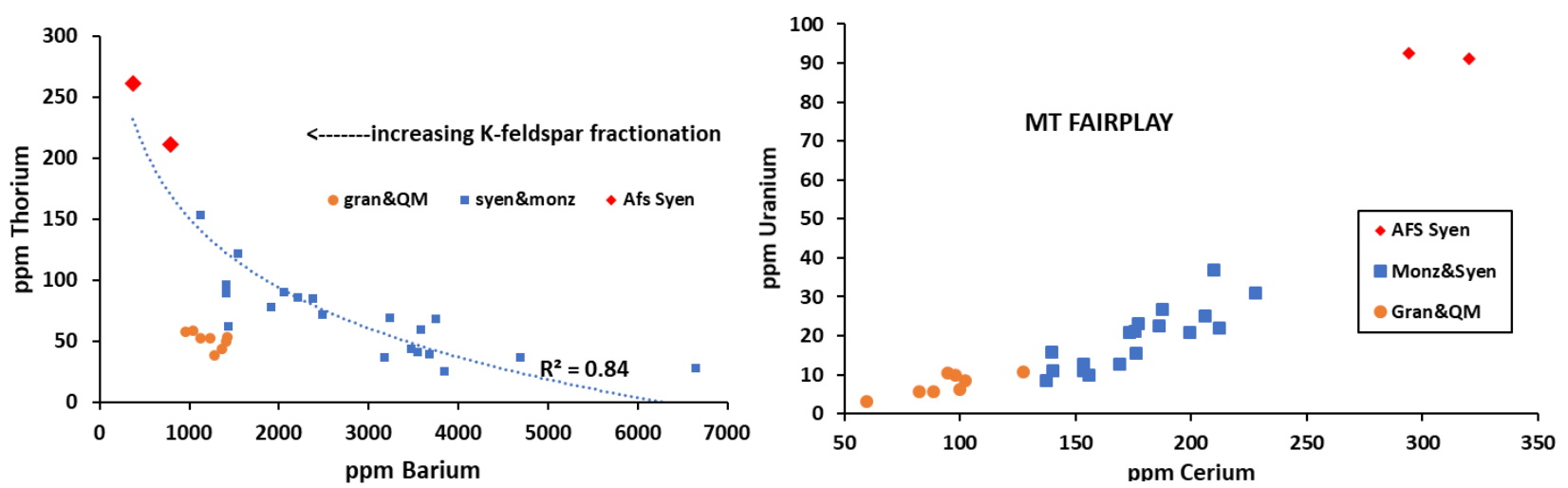

Figure 4. Trace-element plots for Mount Fairplay plutonic rocks. $\mathbf{A}=$ Left, Ba vs. Th. $\mathbf{B}=$ right, Ce vs. U. Geochemical data from Wypych and others (2019). 


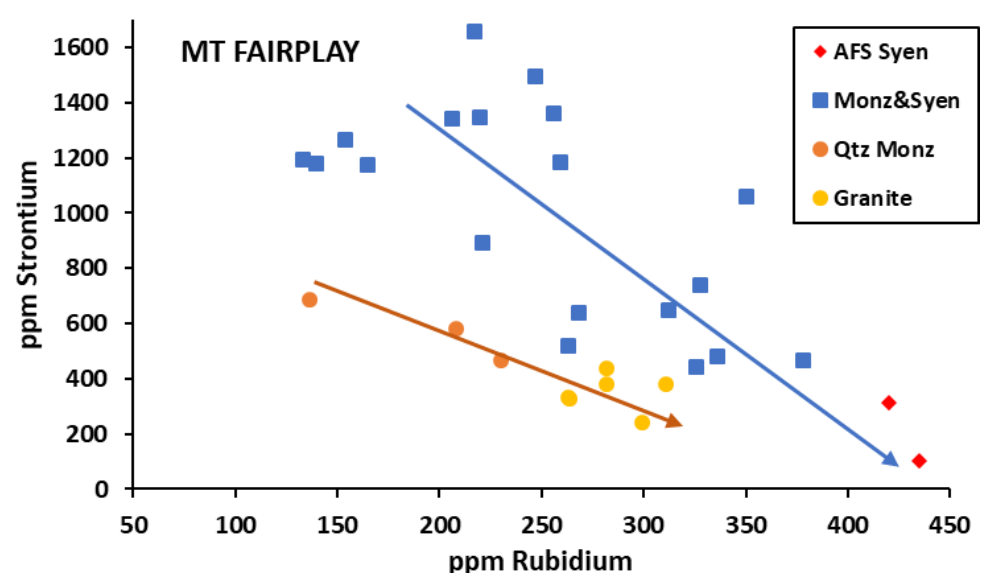

Figure 5. Rb vs. Sr concentrations in Mount Fairplay plutonic rocks, showing different fractionation trends (arrows) for the quartz-rich and quartz-poor rocks. Geochemical data from Wypych and others (2019).

\section{METHODS}

For this study, 24 thin sections were examined, but only the 10 listed in table 1 were examined by Energy-dispersive electron probe microanalysis (EDS-EPMA). The 10 polished sections include at least one example of each rock type spatially distributed throughout the igneous body (fig. 1); in cases of multiple samples, the least-altered ones were chosen for further work. Microprobe energy dispersive spectroscopy (EDS) provided a quick and most-reliable means for conclusively identifying many of the minerals. For example, Kerin (1976) indicated orthopyroxene was present, but none was located in any of the rocks phases examined during this study.

All samples in this report were collected as part of the Alaska Division of Geological \& Geophysical Surveys (DGGS) Eastern Tanacross project during 2019. In DGGS archives and databases each sample number has the prefix "19," which has been eliminated from tables and figures in this report for clarity. For example, sample 19SPR138 is herein abbreviated as "SPR138."

Energy Dispersive Spectroscopy - Electron Probe MicroAnalyses (EDS-EPMA) were performed using the JEOL JXA-8530 Field Emission Electron Probe Microanalyzer at the University of Alaska Fairbanks (UAF) Advanced Instrumentation Laboratory. Analytical beam conditions were $15 \mathrm{keV}$ and current of 45 nA. Energy dispersive spectroscopy (EDS) was undertaken using the Thermo 7 SDD-EDS System and the analyses were reported in the Thermo Scientific ${ }^{\mathrm{Tm}}$ NORAN $^{\mathrm{rm}}$ System 7 X-Ray Microanalysis System (NSS) software. The system was calibrated using well-characterized natural-mineral standards as both analytical standards and analytical blanks. Count times were 60 seconds. Representative mineral analysis are listed in the appendix.

\section{MINERALOGY, MINERAL COMPOSITIONS, AND MINERAL TEXTURES}

In table 1, quartz-rich samples are separated from the quartz-poor samples by a blank row, and within each section, samples are listed by decreasing rock $\mathrm{TiO}_{2}$ concentrations (as an indication of increasing fractionation). It is clear that there are both similarities and differences between the quartz-rich and quartzpoor samples. 
Table 1. Mineralogical summary of microprobed thin sections.

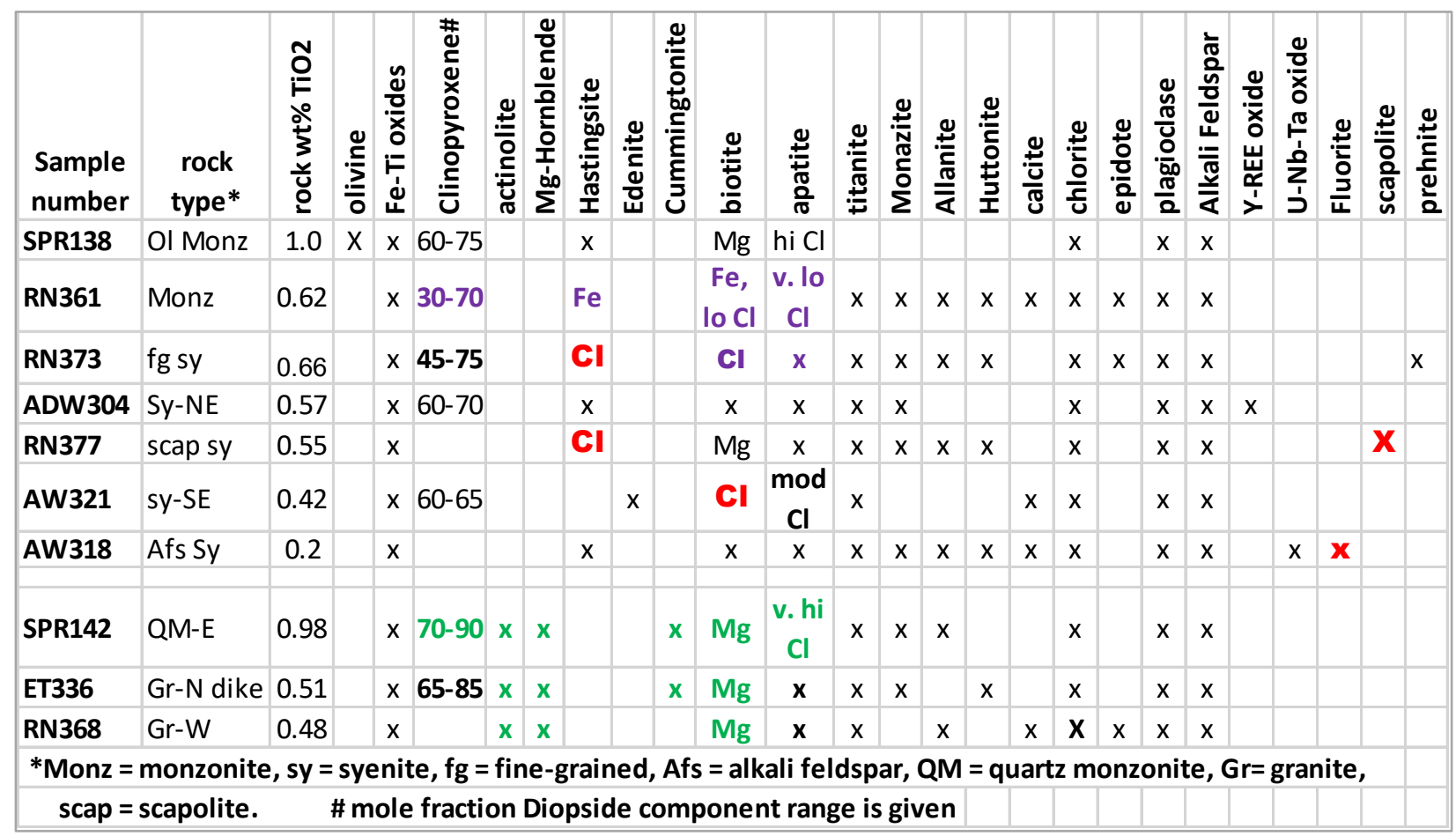

As indicated by the 'at least trace' presence of chlorite (table 1), all samples have experienced some hydrothermal alteration. What is not clear from the mineralogy, however, is that both primary and secondary biotite and amphiboles are present, and that nearly all the rocks record extensive post-magmatic alteration. Nevertheless, all record some aspects of magmatic crystallization as well.

Minerals in minor abundance in these rocks include apatite (0.5-3 normative percent), titanite (0-1 percent), zircon (<0.1 percent), and a host of rare and (or) sporadically occurring minerals (table 1). Of these, the most important are apatite and titanite, as they appear to host the bulk of the rare earth elements (REEs) in the rocks. Titanite is present in all but the 'least altered' olivine monzonite (SPR138), which is part of the evidence that the titanite is mostly of secondary origins.

\section{Olivine}

Iron ( $\mathrm{Fe}$ )-rich olivine ( $\mathrm{Fa}_{63-74}$; fig. $6 \mathrm{~A}$, table $\mathrm{Al}$ ) is present in the least-fractionated monzonite sample (SPR138, fig. 1). This is also among the least-altered samples, as it lacks secondary amphibole and biotite, and the olivine is nearly pristine. Other-more strongly altered-monzonite samples contain reddish patches of very fine-grained intermixed iron oxide and quartz (as determined by EPMA), that is, iddingsite, that most likely represents alteration of iron-rich olivine. 

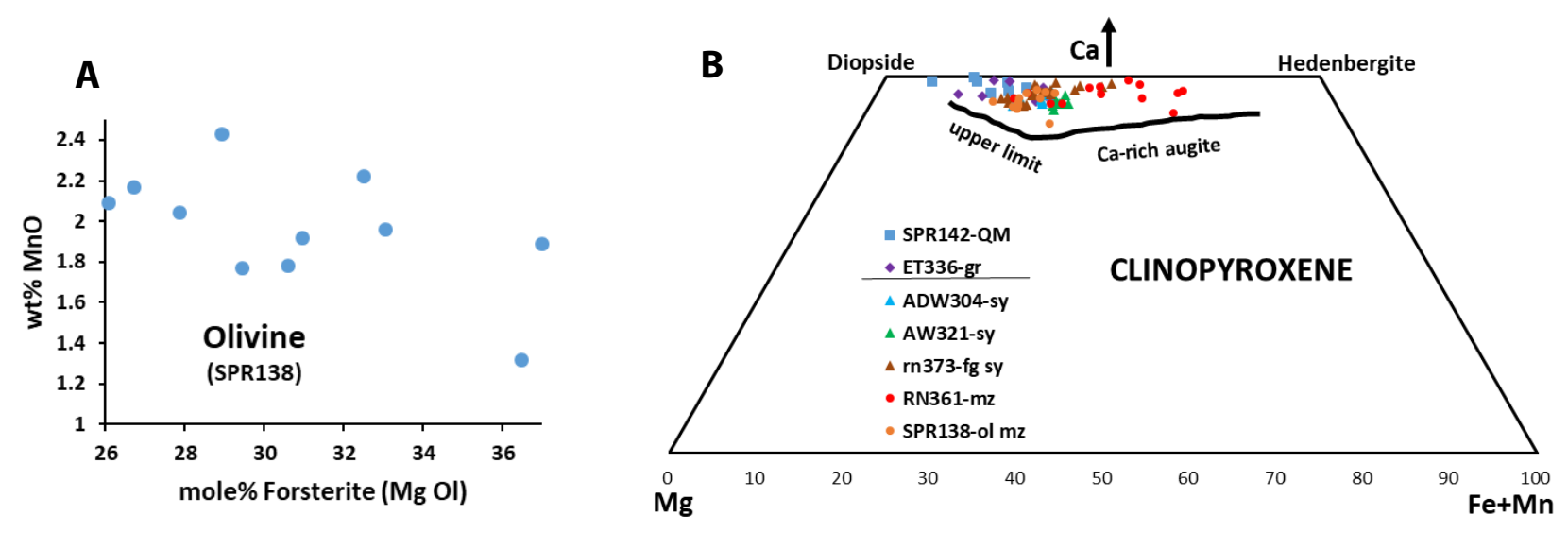

Figure 6. Compositions of olivine (A) and clinopyroxene (B) from Mount Fairplay rocks. Representative data in table A1.

\section{Clinopyroxene}

In comparison, clinopyroxene is nearly ubiquitous and only missing in strongly altered or highly fractionated rocks (table 1). Commonly the clinopyroxene displays no alteration, but it is surrounded by primary biotite or amphibole. The pyroxene is calcium-rich (fig. $6 \mathrm{~B}$, table A1) and compositionally better described as a diopside (most of the samples)-hedenbergite solid solution, rather than as 'augite'. Several of the samples, for example SPR142 (quartz monzonite), contain nearly end-member diopside (table 1); only in sample RN361 (monzonite) is the pyroxene relatively iron-rich (fig. 6B; table 1, table A1). Notably, diopsidic clinopyroxene occurs in one of the samples of granite (ET336), a distinctly unusual combination. However, clinopyroxene in the quartz-rich rocks is more magnesium $(\mathrm{Mg})$-rich $\left(\mathrm{Di}_{65-90}\right)$ than in the quartz-poor rocks $\left(\mathrm{Di}_{35-75}\right.$, mostly $\left.\mathrm{Di}_{60-70}\right)$. That is, the $\mathrm{Fe}$ (hedenbergite) component varies from a low of 10 percent in the quartz monzonite (SPR142) to a high of 70 percent in the monzonite (RN361).

\section{Fe-Ti oxides}

All the rocks examined contain Fe-titanium (Ti) oxide minerals: ilmenite, Ti-bearing magnetite, and essentially Ti-absent magnetite. The latter is of post-magmatic (hydrothermal) origin and is variably present as small grains with secondary minerals or larger grains intergrown with titanite. Ilmenite and Ti-bearing magnetite are present in three textural types: (1) isolated grains; (2) relatively coarse $(0.3-0.5 \mathrm{~mm})$ intergrowths; and, (3) very fine-grained ( $<50$ micron) intergrowths. The last type represents post-magmatic re-equilibration due to 'oxidative exsolution.' The mineral compositions in relatively coarse intergrowths should yield late magmatic conditions; those of very fine intergrowths yield post-magmatic conditions. Plotting such data on the diagram of Anderson and Lindsley (1988) should yield temperature and $\log \mathrm{f}_{\mathrm{O} 2}$ conditions (fig. 7). Due to the elevated Mn contents in the oxides (table A2), the values should be considered approximate, nevertheless, they show significant differences between the quartz-rich and quartz-poor rocks.

Temperatures of final crystallization for these rocks should be approximately $750^{\circ} \mathrm{C}$ (monzonite) to $650^{\circ} \mathrm{C}$ (granite); such temperatures are consistent with those given by the higher-Ti magnetite intersections in figure 7. Except for the alkali-feldspar syenite (AW318), the quartz-poor rocks yield both magmatic and postmagmatic oxidation states in the vicinity of the fayalite-quartz-magnetite (FQM) buffer, consistent with the 
presence (and evidence for) fayalite-rich olivine in the least fractionated rocks (monzonites). Sample AW318 cooled at about 0.5-1 $\log \mathrm{f}_{\mathrm{O} 2}$ unit above the others. In contrast, data for the quartz-rich rocks indicates both magmatic and especially post-magmatic conditions are much more oxidized than the FQM buffer (fig. 7).
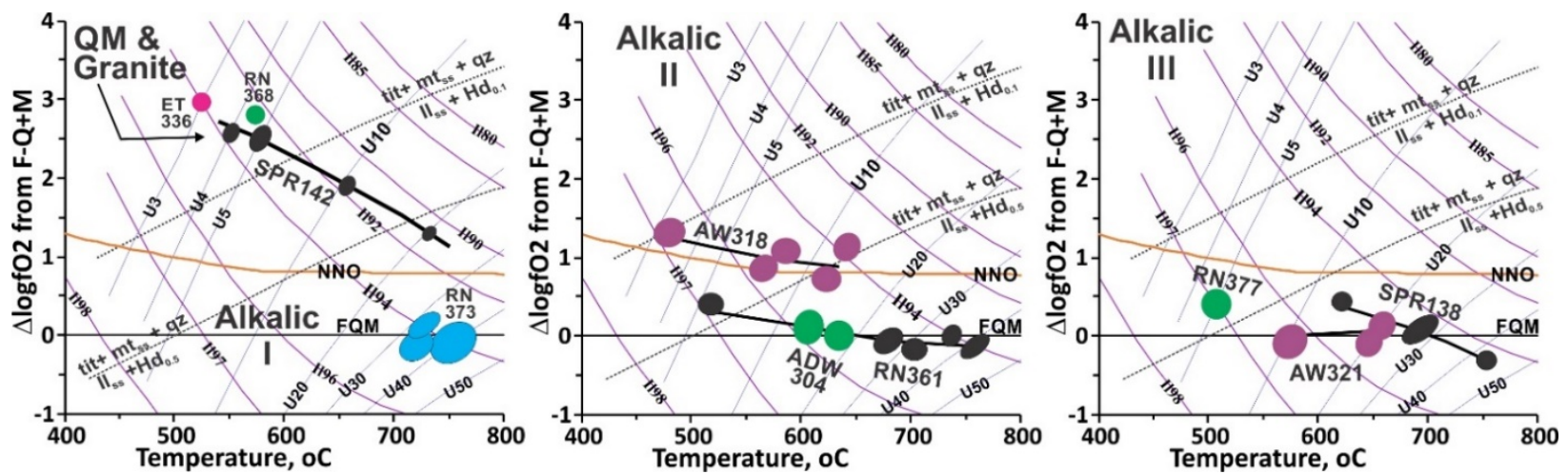

Figure 7. Compositions of co-existing ilmenite and Ti-bearing magnetite grains plotted as mole percentages of ilmenite (II) and ulvospinel (U) on the equilibrium diagram of Andersen and Lindsley (1988). $\mathrm{Log} \mathrm{fO}_{2}$ is depicted as the difference from that of the F-Q-M (fayalite-quartz-magnetite) buffer, as absolute values change tremendously with temperature. Also plotted are the Ni-NiO (NNO) buffer (orange line), and the hedenbergite-llmenite-titanite-magnetite-quartz buffer from Xirouchakis and Lindsley (1998) at different mole fractions of hedenbergite (dashed lines). Data from different samples on the same plot are distinguished by different color ellipses. The ellipses represent 1 standard deviation from the mean values. Representative data in table A2.

The location of the ilmenite ss -hedenbergite ss -titanite-magnetite ss -quartz buffer (ss=solid solution), for two different pyroxene compositions (plot from Xirouchakis and Lindsley, 1998) on figure 7 suggests that for the clinopyroxene compositions seen at Mount Fairplay (fig. 6), the assemblage titanite + magnetite + quartz should only be stable at sub-magmatic and possibly latest-magmatic conditions. Because many of the quartzpoor rocks contain no quartz, the stability of titanite + magnetite extends to somewhat lower $\mathrm{f}_{\mathrm{O} 2}$ and higher temperature. Nevertheless, based on these stability curves, only the granites could have crystallized under conditions where titanite was appreciably stable. As it turns out, this difference in oxidation state between the quartz-rich and quartz-poor rocks is manifested in the compositions of the other iron-bearing minerals of Mount Fairplay.

\section{Amphiboles}

Sodium ( $\mathrm{Na}$ )-Calcium $(\mathrm{Ca})$-bearing amphiboles include a wide range of compositions, which can be generalized as the formula: $(\mathrm{Na}, \mathrm{K})_{0-1}(\mathrm{Na}, \mathrm{Ca})_{2}(\mathrm{Mg}, \mathrm{Fe}, \mathrm{Al}, \mathrm{Ti})_{5}(\mathrm{Al}, \mathrm{Si})_{8} \mathrm{O}_{22}(\mathrm{OH}, \mathrm{F}, \mathrm{Cl})_{2}$. Cations are assigned to amphiboles such that $\mathrm{Na}$ is assigned to the $\mathrm{Ca}$ site so that it contains 2 cations per formula unit (pfu). Excess $\mathrm{Na}+$ potassium $(\mathrm{K})$ are assigned to the first ('A') site, which can contain 0-1 cations pfu. Amphiboles with > 1.5 Ca ions pfu are termed 'calcic', those with less $\mathrm{Ca}$ are termed sodic or sodic-calcic depending on the amount of Ca present (pfu). Almost all of the Mount Fairplay amphiboles analyzed were calcic (table A3), usually with > 1.7 Ca ions pfu. Calcic amphiboles are subdivided based on: (1) amount of alkali in the 'A' site; 
(2) amount of Si pfu; and, (3) atomic $\mathrm{Mg} / \mathrm{Mg}+\mathrm{Fe}+\mathrm{Mn}$. Those with more than $0.5 \mathrm{Na}+\mathrm{K}$ in the 'A' site are commonly termed 'alkali-calcic' those with less 'calcic.'

All of the Mount Fairplay rocks except the alkali-feldspar syenite contain at least some amphibole (table 1). Amphiboles from quartz-rich Mount Fairplay rocks are distinctly different from the quartz poorrocks. The former have lower alkali and higher silica contents than the latter (fig. 8A, B). In particular, nearly all of the amphiboles analyzed from quartz-rich rocks are compositionally Mg-hornblende or actinolite (fig. $8 \mathrm{~A}$ ). Those with actinolitic compositions are texturally secondary and replace both 'primary' Mg-hornblende and diopsidic clinopyroxene. They are commonly associated with fine-grained Ti-poor magnetite and with titanite. Petrographically, the primary hornblende displays green-brown pleochroism and the actinolitic ones display pale green colors. In granite sample ET336 the secondary amphiboles are more Mg-rich than the primary ones; in the other quartz-rich samples the differences are not as clear.

Amphiboles from the quartz-poor rocks are alkali-rich $(\mathrm{Na}+\mathrm{K})_{\mathrm{A}}>0.5$, and Si-poor and Fe-rich (fig. $\mathrm{8B})$ relative to those from quartz-rich rocks. The lower Si contents of the amphiboles are logically related to the lower quartz contents of the rocks; the higher iron is presumably due to lower oxidation state (which stabilizes $\mathrm{Fe}^{2+}$ ). For all but sample AW321, nearly all amphiboles from the quartz-poor rocks plot as 'Hastingsite' (fig. 8B). Those from ADW304 are slightly more Si- and Mg-rich and plot as 'Edenite' instead. There is some relation between amphibole and pyroxene compositions, as samples RN361 and RN373 contain the most Fe-rich pyroxenes and amphiboles; samples AW321 and SPR138 contain the most Mg-rich amphiboles and diopsidic pyroxene (table 1; fig. 8B).

All the rocks with amphiboles contain texturally primary (magmatic) amphiboles; half of them also contain texturally secondary amphiboles. Texturally primary amphibole in the quartz-poor rocks displays brown-green pleochroism and commonly surrounds clinopyroxene or occurs as isolated grains. Texturally secondary amphiboles display blue-green pleochroism and replace both primary amphibole and also clinopyroxene. Texturally secondary amphibole is commonly paler than primary amphibole, despite higher iron content (fig. 8B), which is ascribed to the lower Ti content of the secondary amphibole (fig. 8C).

Texturally secondary amphiboles from both quartz-rich and quartz-poor rocks are distinguished by low $\mathrm{TiO}_{2}$ concentrations (fig. 8C): texturally primary amphiboles contain 0.7-3.6 percent (average about 2 percent) $\mathrm{TiO}_{2}$; texturally secondary amphiboles contain $<0.05-0.7$ percent (average about 0.3 percent) $\mathrm{TiO}_{2}$. Titanite is commonly associated with such texturally secondary amphibole. The Ti may come (at least in part) from the breakdown of primary amphibole; Ca comes from the replacement of Ca pyroxene ( $\sim 22$ percent $\mathrm{CaO}$ ) by calcic amphibole ( $\sim 11$ percent $\mathrm{CaO}$ ). In two of the three cases of secondary amphibole in the quartzpoor rocks, these amphiboles also contain high $\mathrm{Cl}$-typically 1-4 weight percent (fig. 8C). The sample containing amphibole with the highest $\mathrm{Cl}$ content (RN377) also contains high-Cl scapolite (see below). The implication is that in many cases these secondary fluids were Cl-rich and thus presumably of magmatic origins. In contrast, none of the amphiboles from the quartz-rich rocks contain significant $\mathrm{Cl}$ (fig. 8C). Primary clinopyroxene in pyroxene-absent RN377 was likely replaced by reactions that produced secondary scapolite.

Ca-poor amphibole was found in two of the quartz rich-rocks (fig. 8D; table A3). These grains are present in complex textures with the other amphiboles, but appear to be monoclinic (not orthorhombic). Their compositions (fig. 8D) are consistent with the monoclinic amphibole cummingtonite rather than the 
orthorhombic amphibole anthophyllite. In any event, their relatively Fe-poor and Si-rich compositions are consistent with the other amphiboles in the quartz-rich rocks.
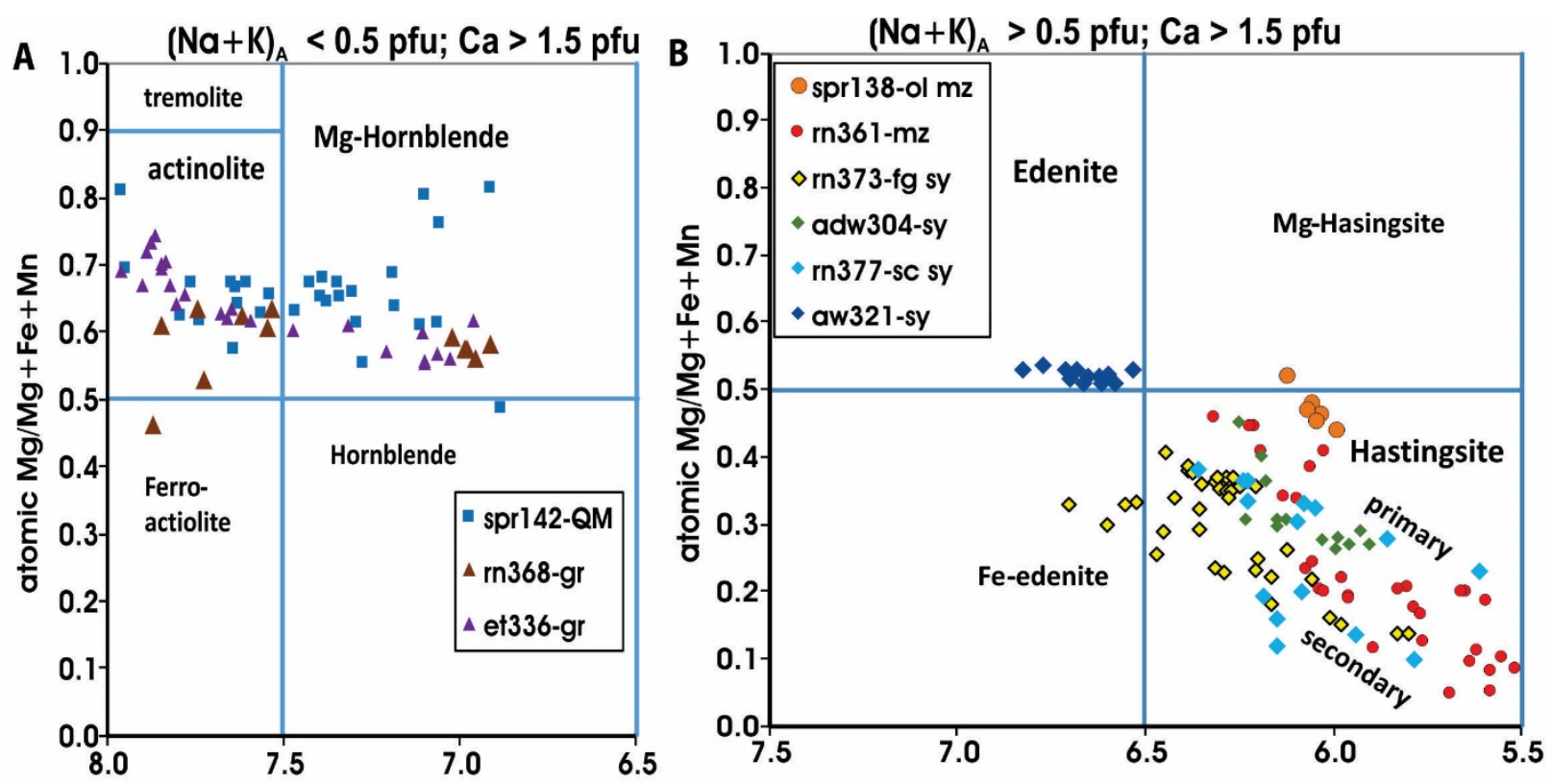

Si atoms per formula unit

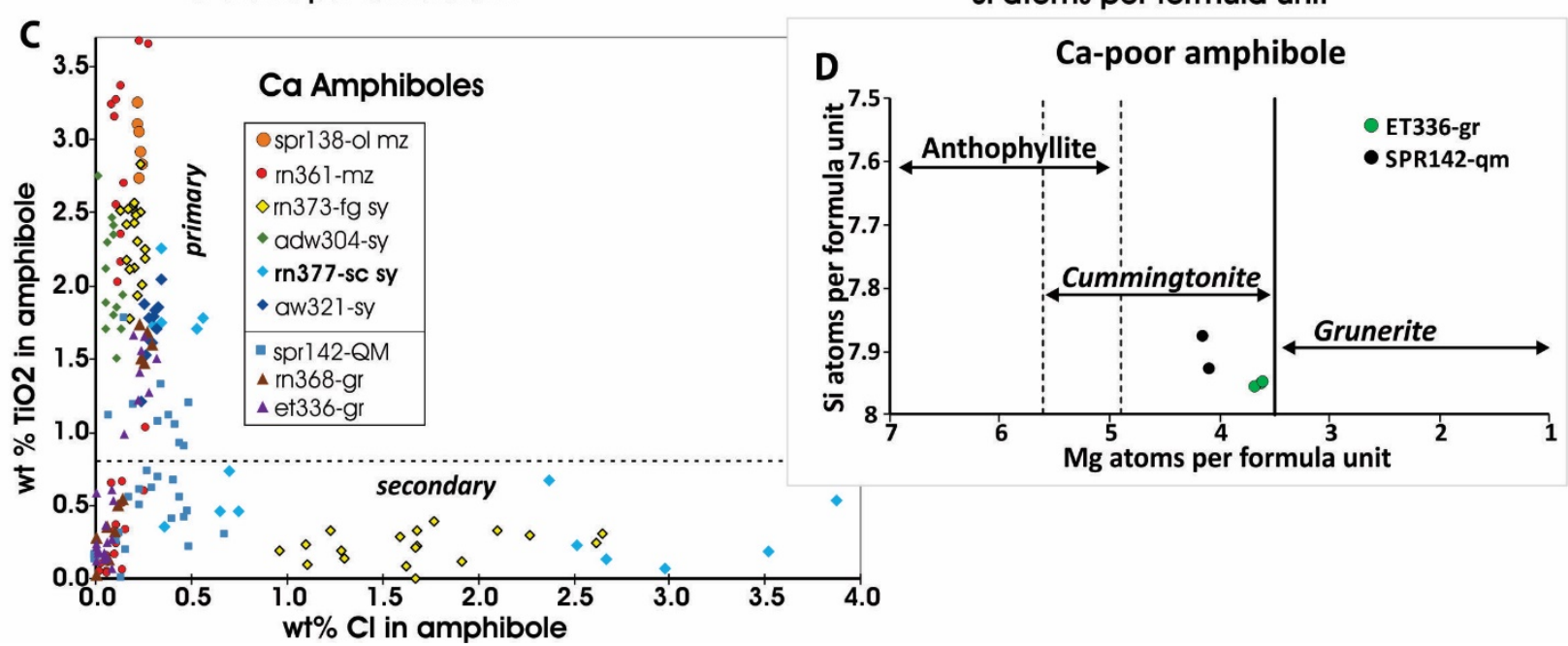

Figure 8. Compositions of amphiboles from the Mount Fairplay complex. Names (A, B, D) and compositional ranges (D) are from Leake and others (1997). Samples are listed by decreasing $\mathrm{TiO}_{2}$ contents of the associated rocks (table 1). Abbreviations for rock types as in table 1, except that sc = scapolite. Representative analyses given in table A3. 


\section{Biotite}

Biotite occurs in all rocks of the Mount Fairplay complex. Biotite in quartz-rich rocks is distinguished from that of the quartz-poor rocks by the former showing little compositional variation, is generally more $\mathrm{Mg}$-rich, and contains only one biotite generation (fig. 9A-C). Petrographically, primary biotite displays brown pleochroism; secondary biotite in these rocks is green or green-brown. Compositionally, primary biotite contains 2.5-8 percent $\mathrm{TiO}_{2}$; secondary biotite contains $<0.1-2$ percent $\mathrm{TiO}_{2}$ (fig. 9). Primary biotite from the quartz-poor rocks typically contains more Fe than that of the quartz-rich rocks (fig. 9A; table A4) and displays a progressive increase in $\mathrm{MnO}$ with decreasing $\mathrm{TiO}_{2}$ (fig. 9B). Primary biotite from the quartzpoor rocks is commonly, but not always, lower in $\mathrm{Cl}$ than that from the quartz-rich rocks (fig. 9C).
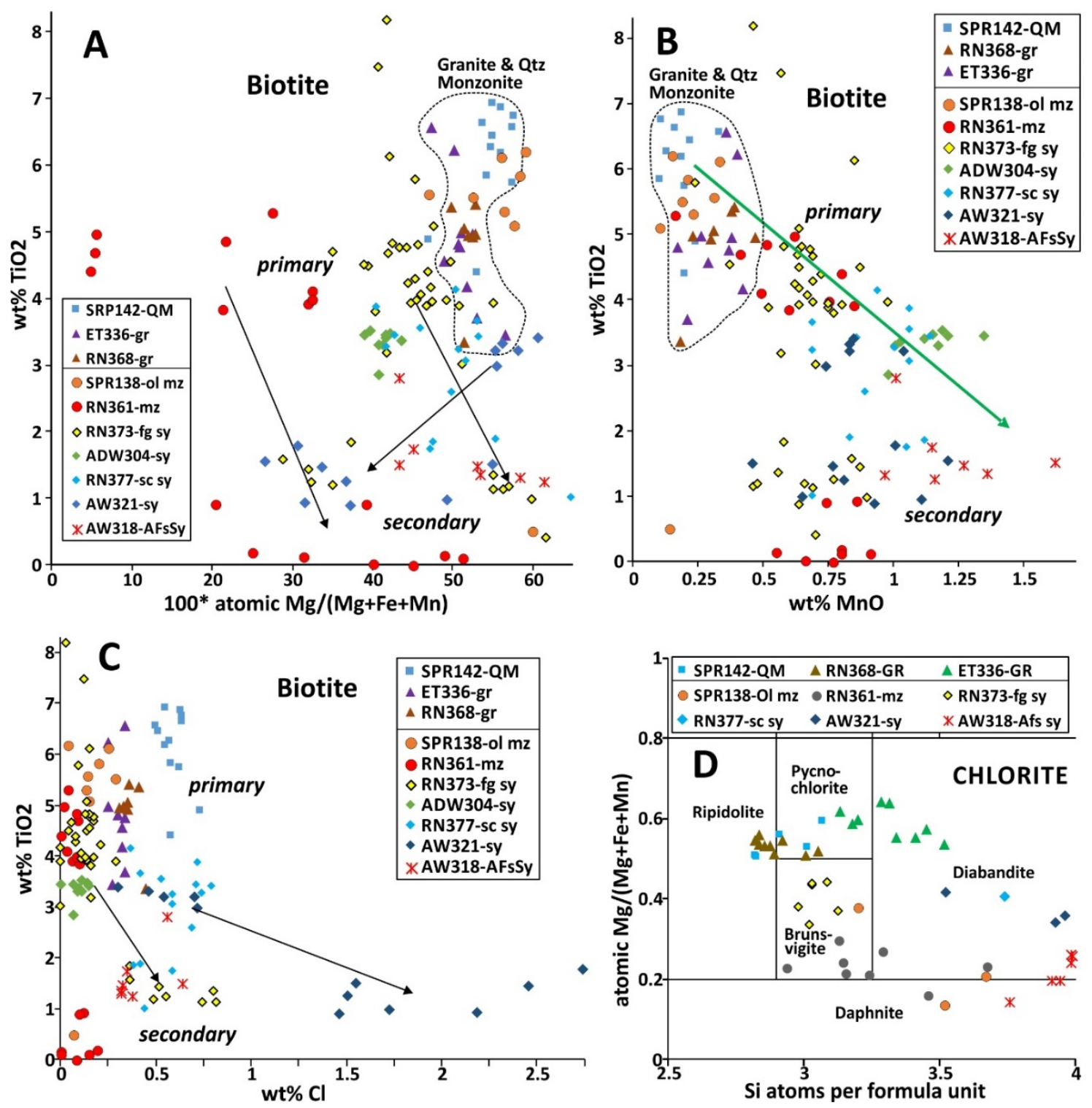

Figure 9. Diagrams showing compositions of biotite (A-C) and chlorite (D) in Mount Fairplay rocks. Chlorite nomenclature from Hey (1954). Representative analyses given in tables A4 and A5. 
Secondary biotite mostly appears to replace primary biotite, but may in part replace hornblende and (or) clinopyroxene; clear-cut evidence for the latter was not found.

Of the quartz-poor rocks, only samples SPR138 (olivine monazite) and ADW304 (syenite) lack secondary biotite; they also lack secondary amphibole (fig. 8C). Secondary biotite is commonly depleted in Fe relative to primary biotite, but not in all cases (fig. 9A). There is apparently no change in $\mathrm{MnO}$ between primary and secondary biotite (fig. 9B). In two samples (RN373 and especially AW321) secondary biotite is enriched in $\mathrm{Cl}$ relative to the primary biotite (fig. 9C).

\section{Chlorite}

Chlorite is present in all of the samples from Mount Fairplay, albeit in small amounts (table 1). Similar to other mineral trends, chlorite in quartz-rich rocks contains higher $\mathrm{Mg}$ than that of the quartz-poor rocks (fig. 9D; table A5). Chlorite is associated with secondary amphibole (actinolite) in the quartz-rich rocks but appears independent of secondary amphibole (and biotite) in the quartz-poor rocks. It likely represents one of the youngest alteration minerals.

\section{Feldspar}

Feldspars occur in all of the Mount Fairplay rocks, both as medium-grained to very coarse-grained phenocrysts and as fine- to medium-grained crystals in the matrix. In addressing feldspar compositions, feldspars with obvious exsolution lamellae were avoided and this study focused on what appeared to be discrete grains. Because sample SPR138 contains essentially unaltered fayalitic olivine and diopsidic pyroxene, it is most representative of original magmatic feldspars-at least for the quartz-poor rocks. Interstitial, apparently secondary, albite-rich ( $\mathrm{An}_{10}$ or less) plagioclase occurs in all the rocks except SPR138 (fig. 9A).

Plagioclase, especially in the granites, occurs as optically zoned phenocrysts; microprobe analyses show they possess normal zoning, with An-rich (up to $\mathrm{An}_{40}$ ) cores and An-poor (to $\mathrm{An}_{14}$ ) rims (fig. 9A). It is striking that the quartz-rich rocks display virtually identical range and average plagioclase compositions. In comparison, the quartz-poor rocks display a broad decrease in average An contents from olivine monzonite to alkali-feldspar granite, complicated by the abundance of secondary albite grains analyzed. The fine-grained syenite ( $\mathrm{RN} 373$ ) displays the greatest range in plagioclase compositions: it contains phenocrysts with cores as calcic as $\mathrm{An}_{52}$ (fig. 9A). The alkali-feldspar syenite contains exclusively albitic plagioclase; this could be the original magmatic mineral (due to extensive fractionation) or might indicate that all the plagioclase microprobed from that sample was secondary.

Alkali feldspars also yield apparently primary and secondary compositions. Based again on data from SPR138, primary alkali feldspars from the quartz-poor rocks are approximately $\mathrm{Or}_{50-80}$, secondary feldspars have compositions $>\mathrm{Or}_{80}$ and $<\mathrm{Or}_{25}$ (fig. 9B). Alkali feldspars from the quartz-rich rocks show a smaller range and more K-rich compositions; both granite and quartz monzonite appear to yield near-identical compositions (fig. 9B). Appreciable barium (Ba) concentrations occur in alkali feldspar of the three rocks with highest weight percent $\mathrm{BaO}$ (the quartz monzonite and the two monzonite samples; fig. 10C, D). The alkali feldspars in these rocks contain zones/bands of high-Ba feldspar, with up to 10 percent celsian (Ba feldspar) component. In contrast, apparently secondary alkali feldspar in these rocks contains minimal Ba (fig. 10C, D). 
A

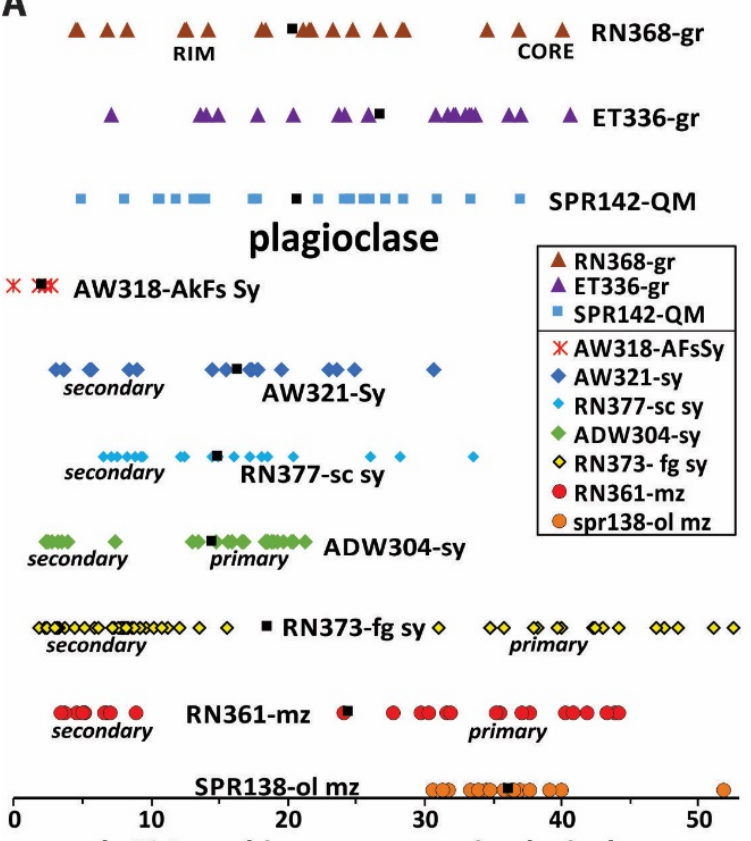

mole \% Anorthite component in plagioclase

C

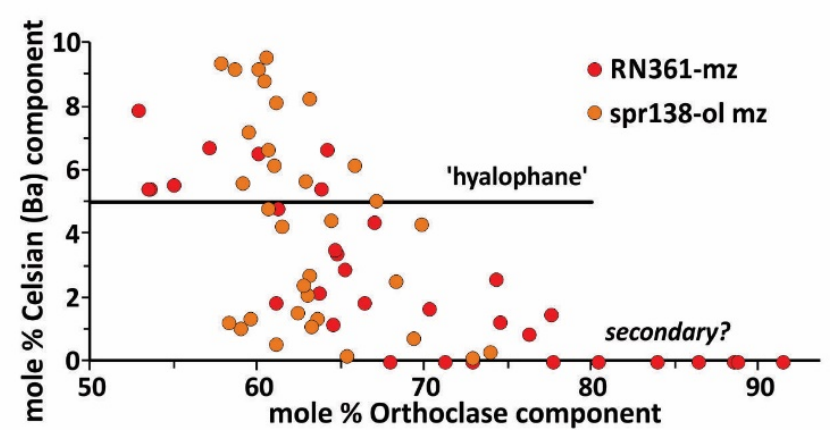

B

D

\begin{tabular}{|lll|}
\hline$\Delta$ RN368-gr & A ET336-gr & " SPR142-QM \\
\hline X AW318-AFsSy & AW321-sy & RN377-sc sy \\
ADW304-sy & $\diamond$ RN373-fg sy & $\bullet$ RN361-mz \\
spr138-ol mz & $\bullet$ AVERAGE & \\
\hline
\end{tabular}

RN368-gr $\Delta \Delta$

ET336-gr $\triangle \Delta A \Delta M$

Alkali feldspar $\quad$ SPR142-QM $=$

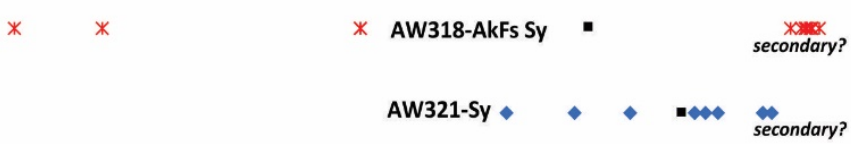

RN377-sc sy secondary

secondary? ADW304-sy $\quad$ primary

RN373-fg sy $\diamond$

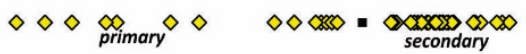

RN361-mz

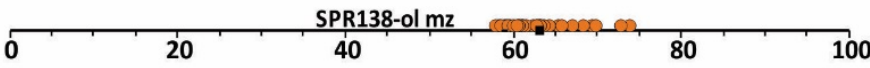

mole \% Orthoclase component in Alkali feldspar

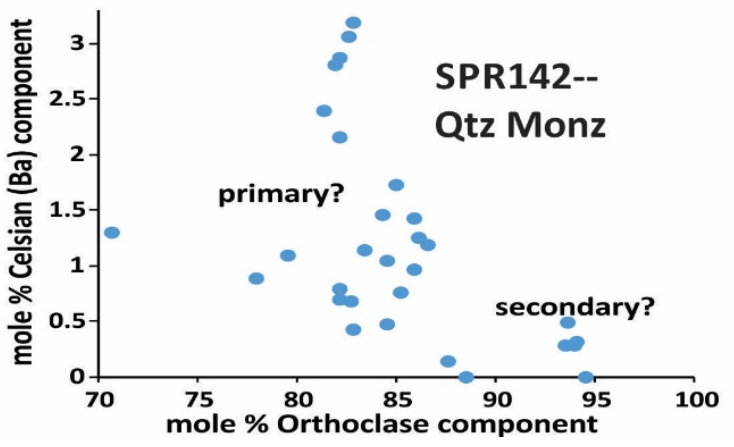

Figure 10. Compositions of Mount Fairplay feldspars plotted in terms of major components. Samples in plots $\mathbf{A}$ and $\mathbf{B}$ are arranged by rock type, with common symbols for a particular rock type. The vertical stacking order is from least fractionated (highest rock $\mathrm{TiO}_{2}$ ) at the base, upward to most fractionated rocks, and quartz-poor rocks below quartz-rich rocks. Plots $\mathbf{C}$ and $\mathbf{D}$ show Ba vs. K components in alkali feldspar for the three samples that contain measurable Ba. Representative analyses given in table A6. 


\section{Apatite}

As seen in backscattered-electron (BSE) images, apatite occurs in Mount Fairplay rocks with two different textures, which are attributed to: (a) initial magmatic crystallization; and, (b) hydrothermal alteration. Magmatic textures are seen in the 'unaltered' olivine monzonite sample (fig. 11A) and in apatite present as inclusions in unaltered mafic minerals in other thin sections (fig. 11B-D). The BSE images show dark, low-REE cores surrounded by multiple zones of bright (REE-rich) rims. The more common texture is samples with three zones: darkest core, lighter mid-section, and brightest rim (fig. 11A, D), but multiple bright rings and irregular bright zones (fig. $11 \mathrm{~B}, \mathrm{C}$ ) also occur. In rocks that display hydrothermal alteration, however, typical apatite shows dark (REE-poor) apatite replacing REE-enriched apatite (fig. 11E-I). Tiny grains of monazite are commonly associated with the alteration, but there does not appear to be sufficient monazite to account for the lost REEs. A less-common texture (fig. 11J) is that of an REE-rich mineral surrounding and replacing apatite. This most commonly occurs as allanite, but huttonite $\left(\mathrm{ThSiO}_{4}\right)$ is also commonly present (fig. 11I).

Compositions of apatite from the 'unaltered' olivine monzonite (SPR128) sample show a decrease in $\mathrm{Cl}$ with an increase in $\mathrm{Ce}$ (fig. 12A). That is, apatite rims are both enriched in $\mathrm{REE}$ and depleted in $\mathrm{Cl}$. Apatite from other quartz-poor samples (especially RN377, AW318, and AW321) follow the general trend of SPR138 (fig. 12A) but most of the apatite compositions plot at lower Ce concentrations than the SPR 128 trend. This is attributed to the leaching of REE from apatite during hydrothermal alteration, as documented in the BSE images (fig. 11E-I).

Apatite from quartz-rich samples does not show any obvious compositional trends (fig. 12B) except for a dramatic decrease in $\mathrm{Cl}$, compared to the quartz-poor rocks. This may reflect greater leaching of REEs from the hydrothermally altered apatite or might reflect weaker degrees of enrichment with fractional crystallization. 

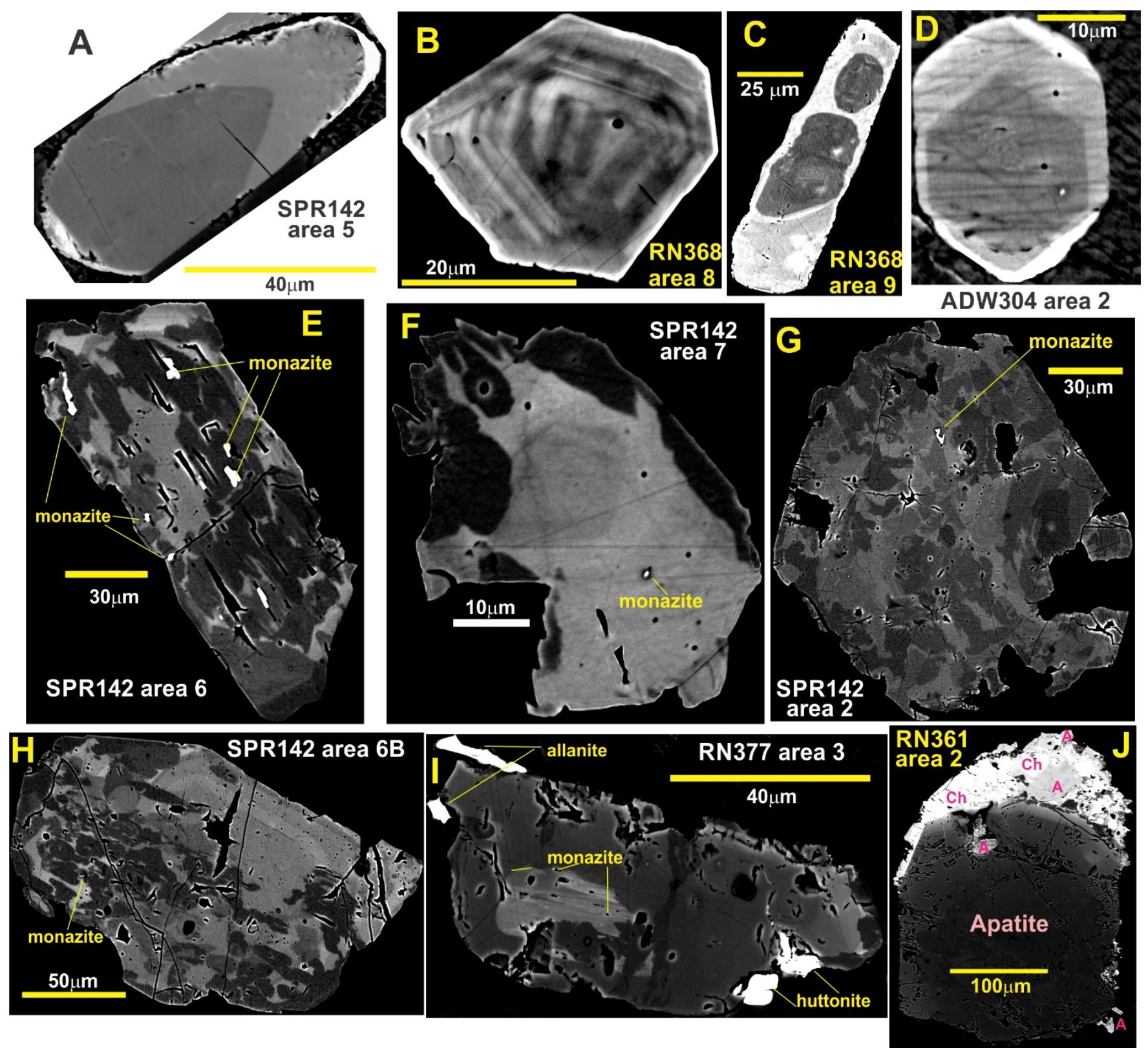

Figure 11. Representative backscattered electron (BSE) images of apatite and associated minerals from rocks of the Mount Fairplay complex. Brighter = higher mean-atomic number; for apatite, this is due to higher concentrations of rare earth elements (REEs). A-D = typical 'primary magmatic' textures, with darker (REE-poor) cores and brighter (REE-rich) rims. Multiple enriched zones are commonly present. E-I = typical 'secondary' textures, with higher REE apatite (brighter) irregularly replaced by darker (REE-poor) apatite. Tiny monazite inclusions are commonly associated with this replacement, as pointed out. J shows a lesscommon texture, with apatite rimed and partly replaced by REE-rich minerals, in this case, allanite (A) and cheralite (ch; $\left.(\mathrm{REE}, \mathrm{Th}, \mathrm{Ca}, \mathrm{U})(\mathrm{P}, \mathrm{Si}) \mathrm{O}_{4}\right)$. Most of the images are from sample SPR142 because this sample has by far the best polish, which allows the BSE images to be most distinct. 


\section{A. Low-quartz rocks}

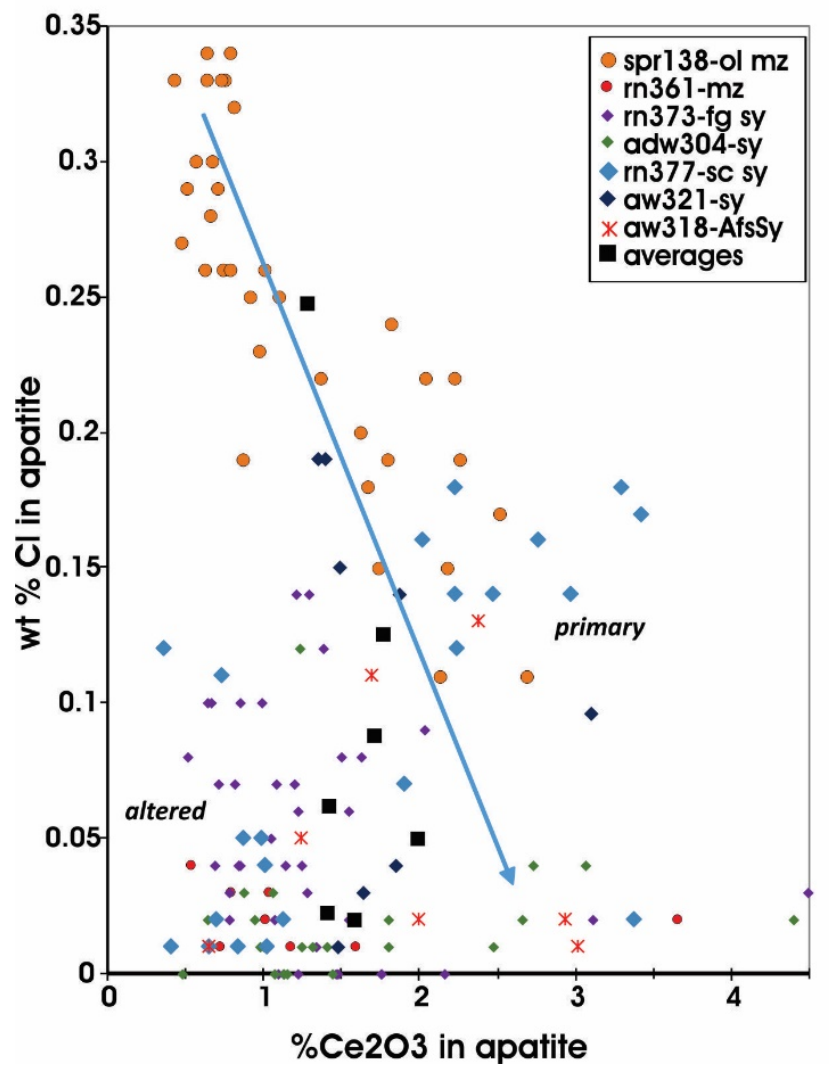

\section{B. Granite \& Qtz Monzonite}

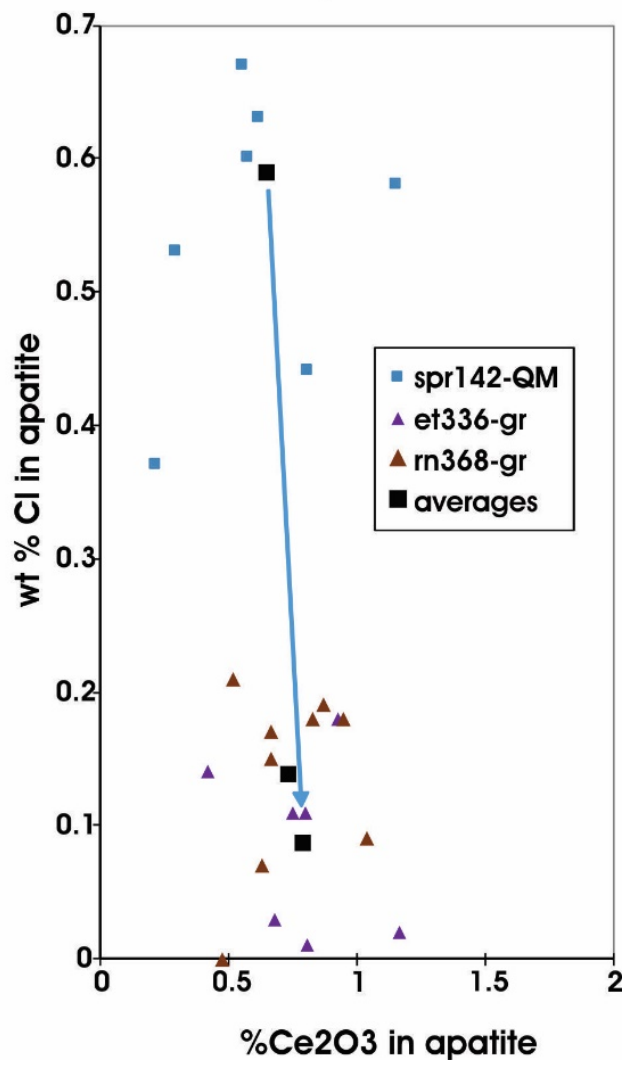

Figure 12. Compositions of apatite from Mount Fairplay rocks for (A) quartz-poor and (B) quartz-rich rocks. Arrows show presumed primary (magmatic) compositional evolution. Data from EDS microprobe. Representative data in table A7.
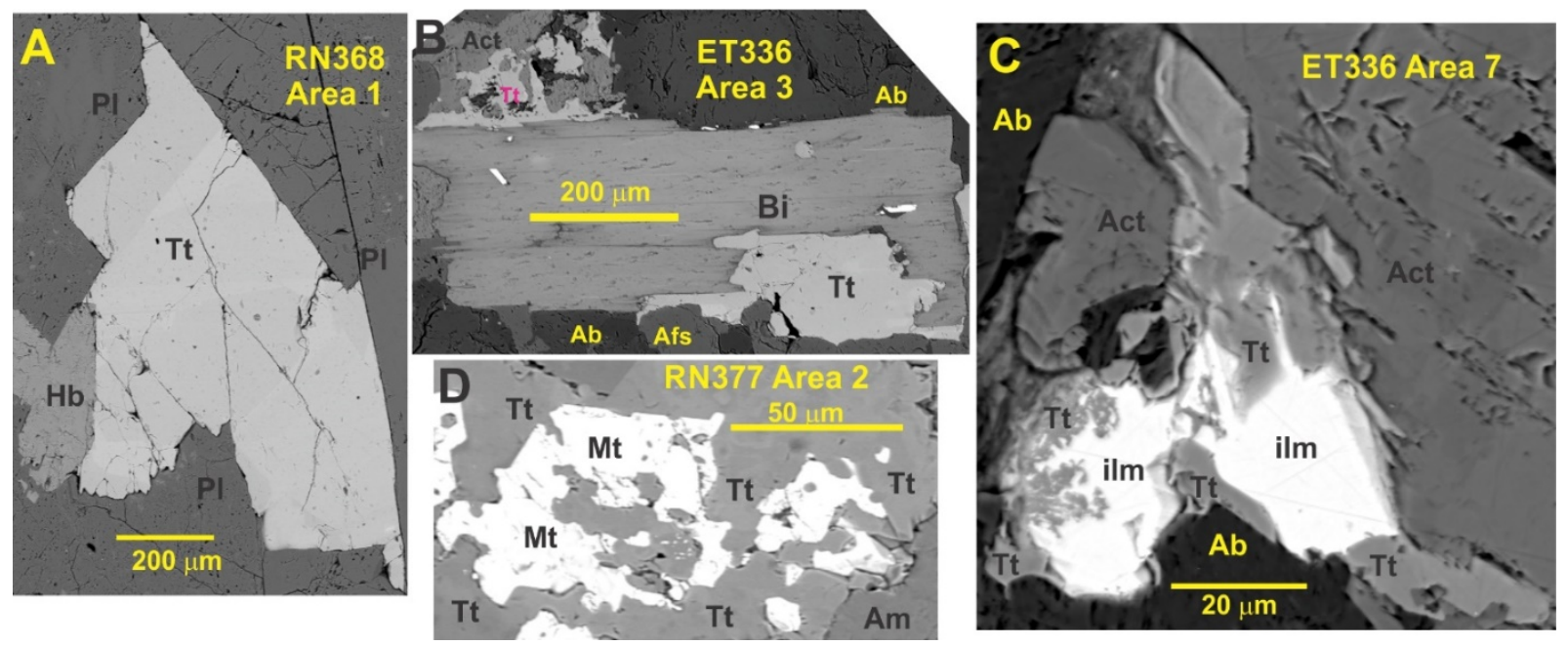

Figure 13. Representative BSE images of titanite textures in rocks of the Mount Fairplay igneous complex. A. Rare, possibly latemagmatic titanite from granite. The titanite is relatively large $(\mathrm{ca} .1 \mathrm{~mm})$ and occurs interstitial to magmatic minerals. B, D. Typical textures of 'clearly' secondary titanite. B=biotite partly replaced by titanite with adjacent intergrown titanite-actinolite-albite. C. Titanite replacement of ilmenite. $\mathrm{D}=$ titanite replacement of Ti-magnetite. Abbreviations: $\mathrm{Tt}=$ titanite, $\mathrm{Hb}=$ hornblende, $\mathrm{Pl}=$ plagioclase, $\mathrm{Act}=$ actinolite $\mathrm{Ab}=$ albite, $\mathrm{Afs}=$ alkali feldspar, $\mathrm{Mt}=$ magnetite, $\mathrm{ilm}=$ ilmenite, $\mathrm{Act}=$ actinolite, $\mathrm{Am}=\mathrm{amphibole}$. 

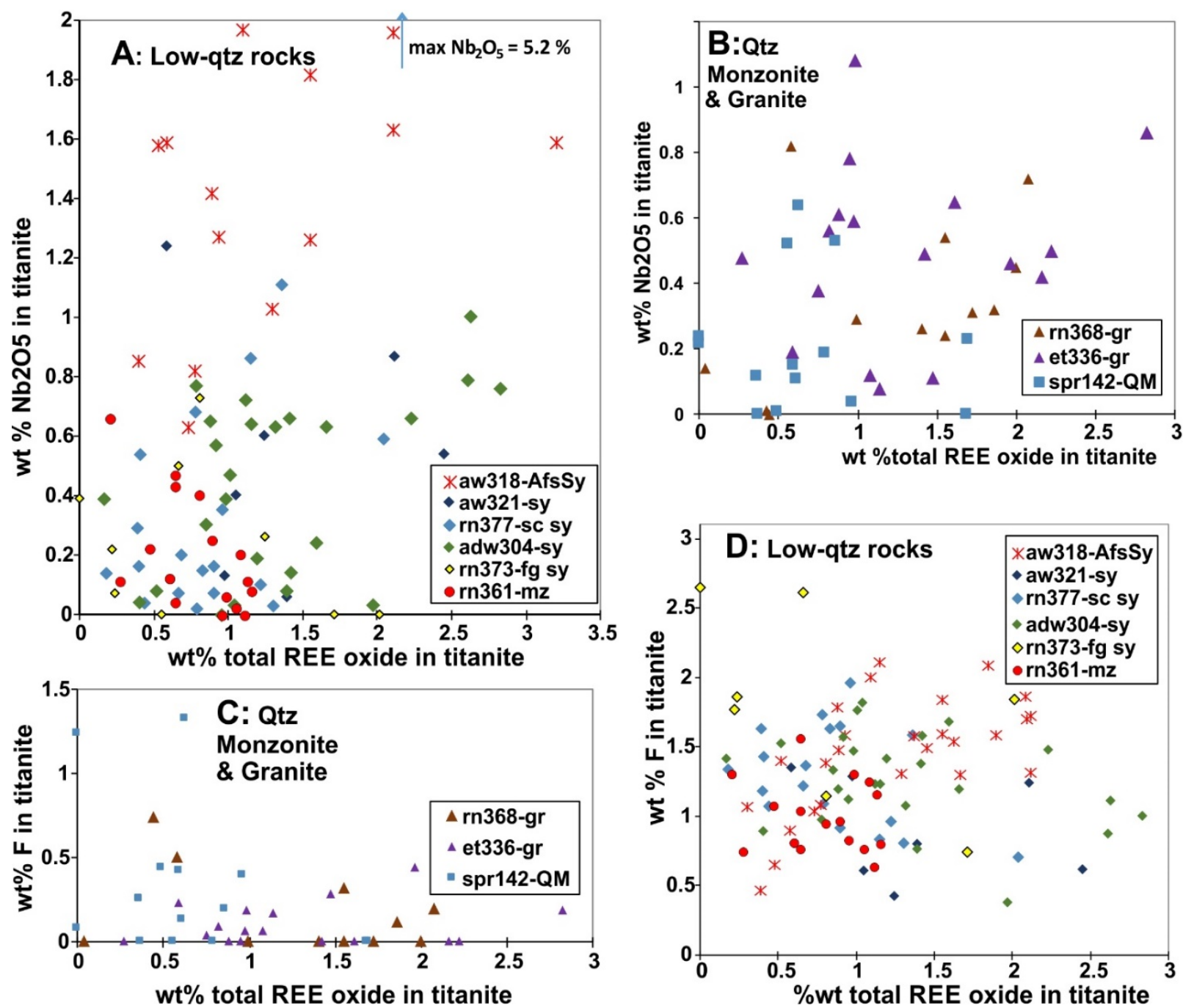

Figure 14. Compositional characteristics of titanite from the Mount Fairplay complex. Data from microprobe EDS. Note that typical igneous titanite contains about 0.5 percent $F$ (Kowallis and others, 2018). Representative data in table A8.

\section{Titanite}

The formula for titanite (sphene) is commonly given as $\mathrm{CaTiSiO}_{5}$, but one which better describes natural titanite is $\mathrm{Ca}(\mathrm{Ti}, \mathrm{Al}, \mathrm{Fe}) \mathrm{SiO}_{4}(\mathrm{O}, \mathrm{OH}, \mathrm{F})$. The coupled substitution $\left(\mathrm{Fe}^{3+}, \mathrm{Al}^{3+}\right)+\left(\mathrm{OH}^{-}, \mathrm{F}^{-}\right)=\mathrm{Ti}^{4+}+\mathrm{O}^{2-}$ causes the more complicated formula. Light REEs substitute for $\mathrm{Ca}^{2+}$ (through several different coupled substitutions); $\mathrm{Nb}^{5+}$ substitutes for $\mathrm{Ti}^{4+}$ (through different coupled substitutions). Consequently, titanite can be an important reservoir for these elements.

All the Mount Fairplay complex rocks contain significant titanite except the 'essentially unaltered' olivine monzonite (SPR128). Titanite occurs rarely as large (1 mm), sub-equant grains of possibly latemagmatic origin (for example, fig. 13A) especially in the quartz-rich rocks, but typically occurs as smaller and (or) more irregularly shaped grains (for example, fig. 13B-D). These grains commonly surround Fe-Ti oxide minerals with apparent reaction relations and occur with clearly secondary minerals (for example, actinolite, 
albite, chlorite). Consequently, it can be inferred that the bulk of titanite, especially in the quartz-poor rocks, is of hydrothermal origin. Calcium was supplied from the replacement of Ca-pyroxene ( 22 percent $\mathrm{CaO})$ by amphibole $(\sim 12$ percent $\mathrm{CaO})$ and the replacement of plagioclase by albite. Ti was supplied from the destruction of Fe-Ti oxide minerals and also primary amphibole and biotite.

Mount Fairplay titanite contains measurable $\mathrm{Nb}$ and light REEs, with no obvious correlation between the two (table A8). Of the various bulk-composition samples analyzed, alkali-feldspar syenites contain by far the highest $\mathrm{Ce}$ (fig. 4B) and $\mathrm{Nb}$ concentrations, and it's not surprising that titanite from the alkali-feldspar syenite has the highest total $\mathrm{REE}$ and $\mathrm{Nb}$ concentrations (fig. 14A). The quartz-rich rocks contain much less bulk Ce (fig. 4B) and Nb than the quartz-poor rocks; despite this, the concentrations of REE and Nb in titanite from the two groups are similar (fig. 14A, B). The lack of correlation between $\mathrm{Nb}$ and total REE in the titanite can be attributed to the fact that they rely on different substitution schemes, and limited confidence in the analyses. The issue is complicated compositional variability in Mount Fairplay titanite (and determined from complex BSE images); with only a dozen or so analyses per thin section, it is unlikely that the 'average' concentrations were captured very well.

The $\mathrm{F}$ content of titanite ought to be a reflection of the abundance of $\mathrm{F}$ in associated fluids, as $\mathrm{Al}$ and Fe are common elements. Kowallis and others (2018), based on about 8,000 microprobe analyses of titanites, found that igneous titanite typically contains about $0.05 \mathrm{~F}$ per formula unit (equivalent to about 0.5 weight percent F); hydrothermal titanite can contain much higher concentrations (up to about $0.3 \mathrm{~F}$ pfu, equivalent to about 3 weight percent F). Quartz-poor rocks from the Mount Fairplay complex commonly contain 1-1.5 percent $F$, with a maximum of about 2.6 percent $F$ (fig. 14D), well above that of typical igneous titanite. In contrast, titanite from quartz-rich rocks contains much lower F, commonly below detection (fig. 14C). This is consistent with the fact that secondary biotite and amphibole from the quartz-poor rocks commonly contain elevated $\mathrm{Cl}$; the secondary hydrous minerals in the quartz-rich rocks do not.

$\mathrm{Nb}$ commonly occurs above detection in ilmenite from quartz-poor rocks of the Mount Fairplay complex. Consequently, it reasonable to postulate that much of the $\mathrm{Nb}$ in the Mount Fairplay igneous rocks is ultimately derived from ilmenite. In contrast, much of the Mount Fairplay apatite displays evidence for fluid-based replacement of REE-rich apatite by REE-poor apatite (fig. $11 \mathrm{E}-\mathrm{I}$ ). It seems reasonable to ascribe the REEs in the Mount Fairplay rocks to the REEs released by such reactions.

\section{Zircon and baddeleyite}

Zircon is another nearly ubiquitous trace mineral that is present in small concentrations in almost all of the samples. What's striking about the zircon is that it displays unusual textures. Typical igneous zircon occurs as single grains, commonly 50-100 microns long and 20-30 microns wide, with euhedral pointed ends. Such zircon displays concentric zoning, which can be seen in BSE (due to periodic changes in U, Th, and Hf concentrations). In contrast, typical zircon from Mount Fairplay rocks occurs as irregularly shaped grains with irregular compositional zoning (fig. 15). In these BSE images, higher Th $\pm \mathrm{U}$ zones are bright, and low Th-U zones are dark. A common texture is bright BSE zircon being replaced by dark zircon; huttonite $\left(\mathrm{ThSiO}_{4}\right)$ is commonly associated with such replacements. Another common texture is zircon coalescence, 
where multiple original grains appear to have coalesced into a single irregular grain, commonly trapping nonzircon inclusions (fig. $15 \mathrm{C}, \mathrm{G}, \mathrm{H})$. In one sample, baddeleyite $\left(\mathrm{ZrO}_{2}\right)$ is being replaced by zircon (fig. 15I).

In contrast, the 'least-altered' olivine monzonite sample (SPR138) appears to contain no zircon; instead, the $\mathrm{Zr}$ exclusively occurs as baddeleyite $\left(\mathrm{ZrO}_{2}\right)$. The occurrence of this mineral presumably follows from the silica undersaturated (olivine-bearing) character of the rock and the absence of subsequent hydrothermal alteration. Some or much of the zircon in the other low-quartz Mount Fairplay rocks also may have begun as $\mathrm{ZrO}_{2}$ and acquired its strange shapes and zoning during hydrothermal replacement of the $\mathrm{ZrO}_{2}$. In contrast, $\mathrm{Zr}$ in the high-quartz rocks presumably started as zircon; these samples exhibit few of the strange textures seen in zircon from the low-quartz rocks.
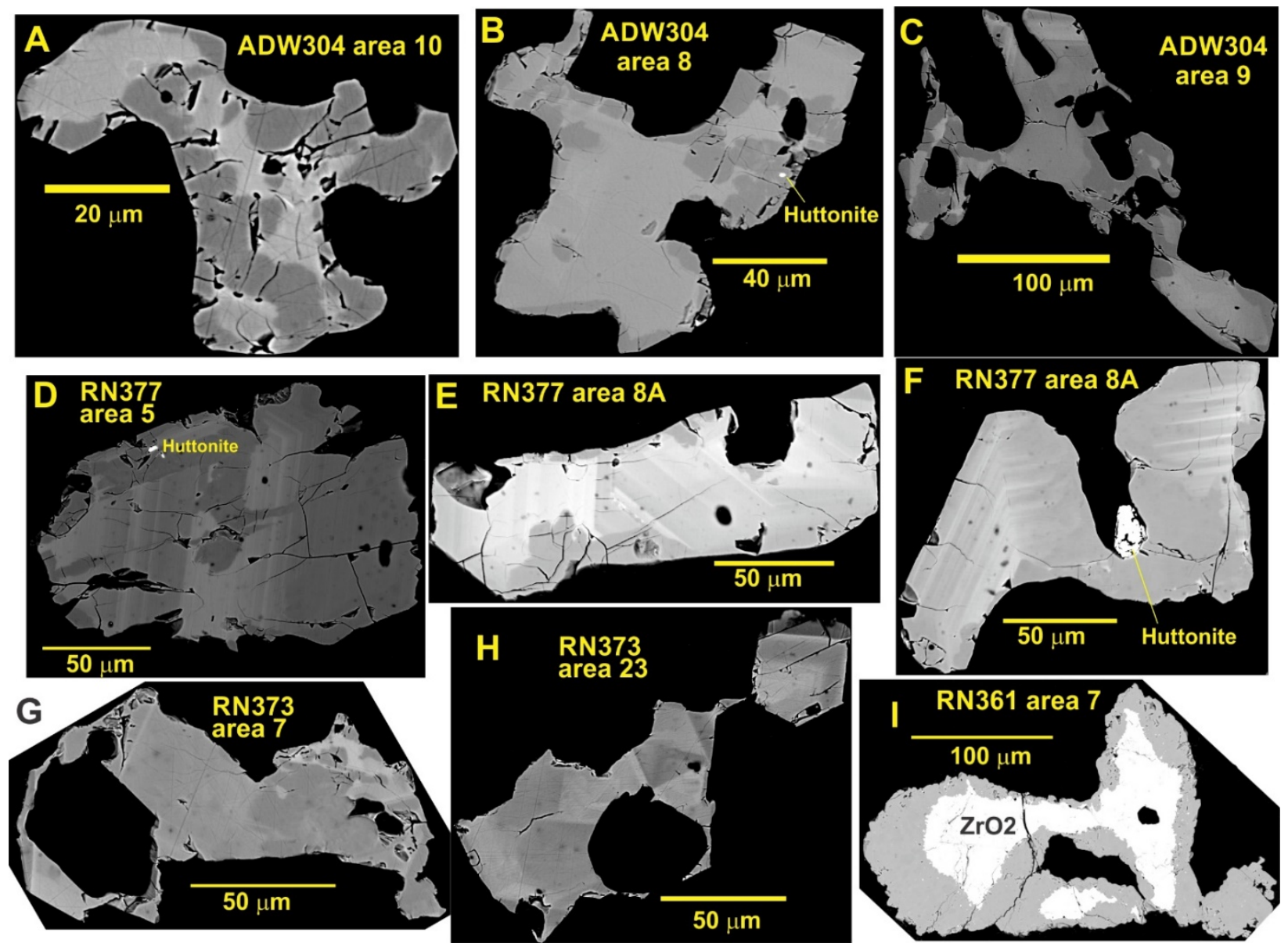

Figure 15. Back-scattered electron (BSE) images of typical Mount Fairplay zircons (A-H). The BSE contrast was set to maximum contrast, so most other minerals (with lower mean atomic weights) appear black. The two exceptions are Huttonite $\left(\mathrm{ThSiO}_{4}\right)$, which commonly occurs with (dark) zones of Th and $U$ leaching $(B, D, F)$ and baddeleyite $\left(\mathrm{ZrO}_{2}\right)$, which is replaced by zircon in sample RN361 (I).

\section{Monazite and Allanite}

Monazite and allanite are present in most of the samples (notably excepting the 'unaltered' olivine monzonite; table 1). These minerals appear to have secondary origins based on their shapes and associations 
with REE-leached apatite (fig. 11). Monazite is rare, typically as tiny ( $<5$ micron) grains in altered apatite; allanite is relatively common and may account for a modest proportion of the REE budget in these rocks.

\section{Other Halogen-bearing minerals}

Minerals restricted to a single sample include fluorite, scapolite, prehnite, and scheelite (table 1). Fluorite was found only in the alkali-feldspar syenite. Its distinctive optical properties (high negative relief, isotropic, good cleavage) make it difficult to miss even if present in small abundances. Similarly, Kerin (1976) only notes fluorite in samples equivalent to the alkali-feldspar syenite. Fluorite was confirmed by microprobe in sample AW318; a single grain of scheelite $\left(\mathrm{CaWO}_{4}\right)$, a hydrothermal mineral, is also present in this sample.

Exploratory XRF analyses of Mount Fairplay thin section billets and other slabs indicate they contain 0.05-0.8 percent $F$, and several contain greater than 0.5 percent $F$. Nevertheless, none but the alkali-feldspar syenite contain obvious fluorite. The additional fluorine may be present in low concentrations in amphibole and biotite as well as apatite and titanite. Due to the overlap between $\mathrm{F} \mathrm{K}_{\alpha}$ and $\mathrm{Fe} \mathrm{L} \alpha \mathrm{X}$-rays, an iron-rich (that is, mafic) mineral must contain several weight percent $\mathrm{F}$ for it to be detected with the microprobe. In other words, all of the low-quartz rocks show evidence for elevated-F fluids (for example, from the F contents of titanite, fig. 14D), despite lacking fluorite.

Based on XRF analyses of thin section billets, sample RN377 has the highest $\mathrm{Cl}$ concentration $(0.18$ percent) and it is the single thin section in which Cl-rich scapolite was identified (table1). The combination of higher relief than plagioclase, and low birefringence, parallel extinction, and columnar habit make scapolite fairly distinctive in thin section (once confirmed by microprobe analysis); and it's at least uncommon in the other Mount Fairplay thin sections examined. It occurs as 1-4 mm patches in sample RN377 and is not visible in hand specimen. The majority of the scapolite is NaCl-rich (fig. 16B), surrounded by a zone of minor $\mathrm{NaCl}$ poor scapolite + albite (fig. 16A).
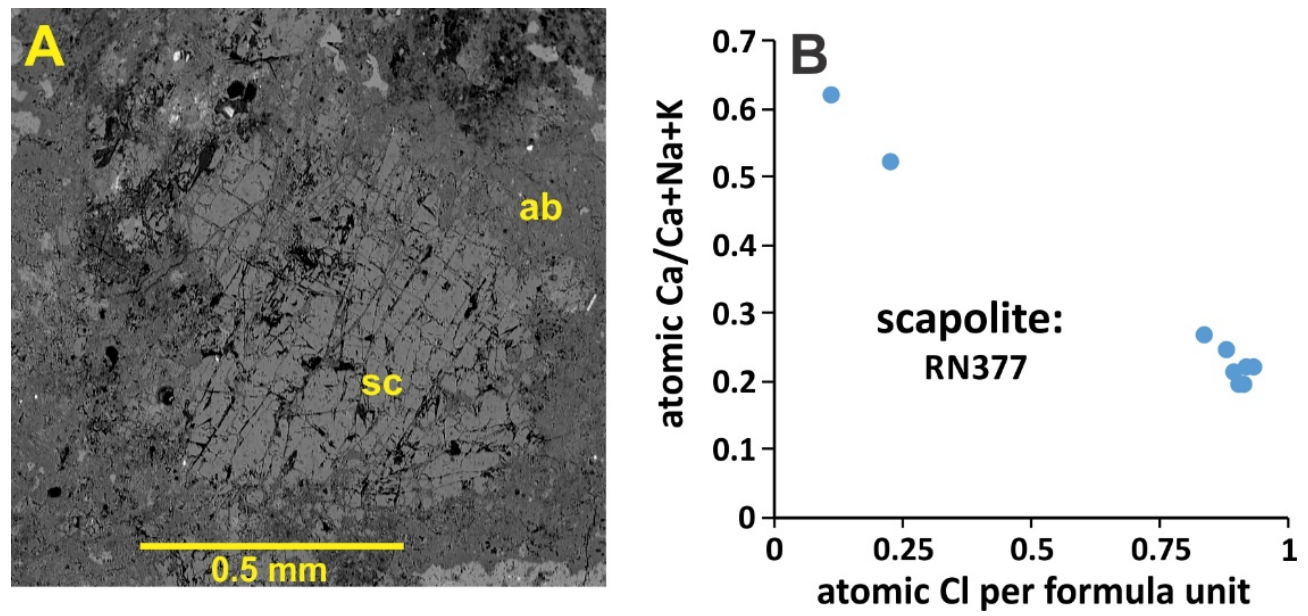

Figure 16. scapolite from sample RN377. A = BSE image, showing elongate scapolite (sc) clot surrounded by darker BSE albite. B = scapolite compositions, showing mostly high Cl contents. 
Sample RN377 contains secondary amphibole with the highest $\mathrm{Cl}$ contents (up to 4 weight percent; fig. 8) and alkali feldspar with exclusively 'secondary' (very K-rich) compositions (fig. 10B). These 'unique' features suggest that scapolite at Mount Fairplay is not common. It's not present in the nearest sample with a thin section, approximately 150 m north of RN377 (fig. 1). Thus, although sample RN377 indicates high-Cl metasomatism, it is of limited spatial extent.

Small patches of prehnite were found in sample RN373 (table 1), near the south edge of the Mount Fairplay complex (fig. 1). One can consider it a low-temperature equivalent to epidote, and as such, perhaps evidence for very low-temperature alteration.

\section{SUMMARY AND CONCLUSIONS}

The Mount Fairplay complex consists of approximately 60 percent quartz-rich and 40 percent quartz-poor igneous rocks (fig. 1). The former shows no REE enrichment; the latter shows a slight REE enrichment with increasing fractionation (fig. 4). That is, nearly two-thirds of the complex is of no interest with regards to REEs.

In the least-altered quartz-poor rocks, REEs display core-to-rim enrichment in apatite, suggesting that REEs became concentrated in magma during fractional crystallization. This feature is also consistent with the overall rise in REE rock content from least (olivine monzonite) to most (alkali-feldspar syenite) fractionated rock. However, most of the rocks display at least some hydrothermal alteration, including replacement of REE-enriched apatite by REE-depleted apatite. Some of the leached REEs were redeposited as minor monazite, allanite, huttonite, and cheralite; however, most were apparently re-deposited along with $\mathrm{Nb}$ within hydrothermal titanite. Hydrothermal Ti was generated during replacement of Ti-rich primary biotite and hornblende by Ti-poor secondary (hydrothermal) biotite and hornblende. The most strongly fractionated (and rare) rocks (alkali-feldspar syenite) contain the highest REE concentrations, present mostly in REEenriched titanite.

The variable presence of high-Cl secondary amphibole and biotite in the quartz-poor rocks, the presence of unusually high $\mathrm{F}$ in the titanite, and the presence of high-Cl scapolite all indicate that these hydrothermal fluids contained relatively high $\mathrm{Cl}$ and F concentrations. Salvi and Williams-Jones (2005) document that igneous-related REE deposits invariably occur with either carbonatites or else with high-F metasomatism. However, the mapped extent and intensity of this metasomatism exposed on the surface at Mount Fairplay appears to be relatively limited. The most REE-enriched phase of the complex is the alkali-feldspar syenite, which constitutes about 1 percent of the complex (fig. 1) and contains less than 1 percent disseminated fluorite.

In the 'least-altered' olivine monzonite sample, $\mathrm{Zr}$ appears to exclusively occur as baddeleyite, which presumably follows from the silica-undersaturated (olivine-bearing) character of the rock. In the other lowsilica rocks, $\mathrm{Zr}$ occurs as irregularly shaped, \pm coalesced zircon grains with irregular compositional zoning; higher $\mathrm{Th} \pm \mathrm{U}$ zones are commonly replaced by low $\mathrm{Th}-\mathrm{U}$ zones and huttonite is often associated with such replacements. Some or much of the $\mathrm{Zr}$ in the low-quartz Mount Fairplay rocks may have begun as baddeleyite and acquired its strange shapes and zoning during hydrothermal replacement by zircon. These observations are consistent with the mobility of Zr being most common in F-rich hydrothermal systems related to alkalic, 
F-rich igneous suites (Rubin and others, 1993). In contrast, $\mathrm{Zr}$ in the high-quartz rocks presumably started as zircon as these samples exhibit few of the strange textures seen in zircon from the low-quartz rocks.

Follow-up work at Mount Fairplay might include soil sampling and detailed radiometric surveying in order to prospect for larger volumes and higher intensities of F-metasomatized and REE-enriched rock.

\section{ACKNOWLEDGMENTS}

This material is based upon work partially supported by the U.S. Geological Survey under Cooperative Agreement No. G19AC00262, part of the Earth Mapping Resources Initiative (Earth MRI) program. It is primarily supported by matching funds from the State of Alaska. The views and conclusions contained in this document are those of the author and should not be interpreted as representing the opinions or policies of the U.S. Geological Survey. Mention of trade names or commercial products does not constitute their endorsement by the U.S. Geological Survey. 


\section{REFERENCES}

Andersen, D.J., and Lindsley, D.H., 1988, Internally consistent solution models for Fe-Mg-Mn-Ti oxides: Fe-Ti oxides: American Mineralogist, v. 73, p. 714-726.

Currie, K.K., 1973, The Alkaline Rocks of Canada: Geological Survey of Canada Bulletin, v. 239, Department of Energy, Mines \& Resources, Canada, 228 p.

Emond, A.M., Saltus, R.W., Graham, Gina, and Goldak Airborne Surveys, 2015, Airborne magnetic geophysical survey of the Tanacross region, Alaska: Alaska Division of Geological \& Geophysical Surveys Geophysical Report 2015-6. http://doi.org/10.14509/29514

Foster, H.L., 1967, Geology of the Mount Fairplay area, Alaska: U.S. Geological Survey Bulletin 1241-B, p. B-1B18, 1 sheet, scale 1:63:360.

Heinrich, E.W., 1980, The Geology of Carbonatites: Krieger Publ. Co., Huntington, N.Y., 585 p.

Hey, M.H., 1954, A new review of the chlorites: Mineralogical Magazine, v. 30, p. 277-292.

Higgins, J.B. and Ribbe, P.H., 1976, The crystal chemistry and space groups of natural and synthetic titanites: American Mineralogist, v. 61, p. 878-888.

Kerin, L.J., 1976, The reconnaissance petrology of the Mt. Fairplay igneous complex: Fairbanks, Alaska, University of Alaska Fairbanks, M.S. thesis, 95 p.

Kowallis, B.J., Christiansen, E.H, Dorais, Michael, Winkel, Tony, Henze, Porter, Franzen, Lauren, and Webb, Haley, 2018, Compositional Variation of Fe, Al, and F in titanite (sphene) [abs.]: Geological Society of America Abstracts with Programs, v. 50, n. 6, abstract 137-11.

Leake, B.E., and 21 others, 1997, Nomenclature of amphiboles: Report of the subcommittee on amphiboles of the International Mineralogical Association, Commission on new minerals and mineral names: The Canadian Mineralogist, v. 35, p. 219-246.

Rubin, J.N., Henry, C.D., and Price, J.G., 1993, The mobility of zirconium and other "immobile" elements during hydrothermal alteration: Chemical Geology, v. 110, n. 1-3, p. $29-47$.

Salvi, Stefano, and Williams-Jones, A.E., 2005, Alkaline granite-syenite deposits, in Linnen, R.L., and Samson, I.M., eds., Rare element chemistry and Mineral Deposits: Geological Association of Canada, GAC short course notes 17, p. 315-341.

Streckeisen, A.L., and Le Maitre, R.W., 1979, A chemical approximation to the modal QAPF classification of the igneous rocks: Neues Jahrbuch für Mineralogie Abh., v. 136, p. 169-206.

Wilson, F.H., Hults, C.P., Mull, C.G., and Karl, S.M., 2015, Geologic map of Alaska: U.S. Geological Survey Scientific Investigations Map 3340, 196 p., 2 sheets, scale 1:1,584,000. http:/alaska.usgs.gov/science/geology/state map/interactive map/AKgeologic map.html

Wypych, Alicja, Twelker, Evan, Athey, J.E., Newberry, R.J., Lopez, J.A., Regan, S.P., Sicard, K.R., Wildland, A.D., and Wyatt, W.C., 2019, Major-oxide and trace-element geochemical data from rocks collected in 2019 for the Eastern Tanacross project, Tanacross and part of Nabesna quadrangles, Alaska: Alaska Division of Geological \& Geophysical Surveys Raw Data File 2019-8, 3 p. http://doi.org/10.14509/30267

Xirouchakis, Dimitrios, and Lindsley, D.H., 1998, Equilibria among titanite, hedenbergite, fayalite, quartz, ilmenite, and magnetite: Experiments and internally consistent thermodynamic data for titanite: American Mineralogist, v. 83, p. 712-725. 


\section{APPENDIX: REPRESENTATIVE EXAMPLES OF ENERGY DISPERSIVE ELECTRON MICROPROBE ANALYSES OF MAJOR MINERALS FROM THE MOUNT FAIRPLAY IGNEOUS COMPLEX}

The following pages give microprobe analyses of the various minerals, presented by mineral group. Each analysis gives the weight percent (wt\%) measured (normalized to a total of 100 percent) and the computed ions per formula unit. In nearly all cases the formula unit is based on the number of oxygens in the waterabsent mineral formula, for example, 11 for biotite (the formula $\mathrm{K}(\mathrm{Fe}, \mathrm{Mg})_{3} \mathrm{AlSi}_{3} \mathrm{O}_{10}(\mathrm{OH})_{2}$ is re-cast as $\left.\mathrm{K}(\mathrm{Fe}, \mathrm{Mg})_{3} \mathrm{AlSi}_{3} \mathrm{O}_{11}\left(\mathrm{H}_{2} \mathrm{O}\right)\right)$. Because titanite contains a variable $\mathrm{OH}+\mathrm{F}$, however, its formula unit is based on four $\mathrm{Si}$ in the unit cell (following Higgins and Ribbe, 1976). Analyses are identified by sample number and then a code: for example, 'A4p13' stands for 'Area 4, point 13'. An 'area' is typically $0.1-0.3 \mathrm{~mm}$ by $0.1-0.3$ $\mathrm{mm}$ and the numbers simply refer to the order in which the areas were chosen during a microprobe session. A given area typically contains $4-8$ different minerals. 
Table A1. Representative Analyses of clinopyroxene and olivine

\begin{tabular}{|c|c|c|c|c|c|c|c|c|c|c|c|c|}
\hline & \multicolumn{3}{|c|}{ RN361 } & \multicolumn{3}{|c|}{ SPR138 } & \multicolumn{3}{|c|}{ ADW304 } & \multicolumn{3}{|c|}{ RN373 } \\
\hline wt\% & A4p6 & A4p6 & A6p2 & | A1p9 & A5p4 & A5p8 & | A1p1 & A1p3 & A1p5 & |A4p2 & A4p4 & A4p7 \\
\hline $\mathrm{SiO}_{2}$ & 50.3 & 49.7 & 52.2 & 50.4 & 50.7 & 51.2 & | 51.4 & 51.7 & 51.6 & | 51.5 & 49.9 & 51.9 \\
\hline $\mathrm{Al}_{2} \mathrm{O}_{3}$ & 2.64 & 0.26 & 0 & | 2.06 & 2.08 & 1.91 & | 1.48 & 0.97 & 1.58 & | 1.88 & 1.85 & 1.9 \\
\hline $\mathrm{TiO}_{2}$ & 0.97 & 0 & 0 & 0.43 & 0.72 & 0.65 & | 0.64 & 0.36 & 0.79 & | 0.42 & 0 & 0.78 \\
\hline $\mathrm{MgO}$ & 11.3 & 5.59 & 8.92 & 11.2 & 12.3 & 12.2 & 10.9 & 11.3 & 11.8 & | 10.4 & 8.28 & 12.2 \\
\hline $\mathrm{MnO}$ & 0 & 1.01 & 0.83 & 0.6 & 0.45 & 0.45 & 0.87 & 0.59 & 0.72 & 0 & 0.83 & 0.79 \\
\hline $\mathrm{FeO}$ & 10.5 & 20.2 & 14.8 & 11.4 & 9.56 & 10 & 10.9 & 11.2 & 9.8 & 12.3 & 15.1 & 8.98 \\
\hline $\mathrm{Na}_{2} \mathrm{O}$ & 0.53 & 1.01 & 0.84 & 0.77 & 0.61 & 0.45 & | 1.54 & 0.9 & 1.63 & 0.71 & 0.96 & 0.7 \\
\hline $\mathrm{CaO}$ & 23.8 & 22.2 & 22.5 & | 23.1 & 23.6 & 23.1 & | 22.3 & 23 & 22.1 & | 22.8 & 23.1 & 22.7 \\
\hline \multicolumn{2}{|c|}{ cat/60 } & & & | & & & | & & & | & & \\
\hline Si & 1.91 & 1.98 & 2.01 & | 1.92 & 1.92 & 1.93 & | 1.95 & 1.97 & 1.95 & | 1.96 & 1.94 & 1.95 \\
\hline $\mathrm{Al}$ & 0.12 & 0.01 & 0 & 0.09 & 0.09 & 0.09 & | 0.07 & 0.04 & 0.07 & | 0.08 & 0.08 & 0.08 \\
\hline $\mathrm{Ti}$ & 0.03 & 0 & 0 & 0.01 & 0.02 & 0.02 & | 0.02 & 0.01 & 0.02 & 0.01 & 0 & 0.02 \\
\hline $\mathrm{Mg}$ & 0.64 & 0.33 & 0.51 & 0.63 & 0.69 & 0.69 & | 0.62 & 0.64 & 0.67 & 0.59 & 0.48 & 0.68 \\
\hline $\mathrm{Mn}$ & 0 & 0.03 & 0.03 & 0.02 & 0.01 & 0.01 & | 0.03 & 0.02 & 0.02 & 10 & 0.03 & 0.03 \\
\hline $\mathrm{Fe}$ & 0.33 & 0.67 & 0.48 & 0.36 & 0.3 & 0.32 & | 0.35 & 0.36 & 0.31 & 0.39 & 0.49 & 0.28 \\
\hline $\mathrm{Na}$ & 0.04 & 0.08 & 0.06 & 0.06 & 0.04 & 0.03 & | 0.11 & 0.07 & 0.12 & 0.05 & 0.07 & 0.05 \\
\hline $\mathrm{Ca}$ & 0.97 & 0.95 & 0.93 & 0.95 & 0.96 & 0.94 & 0.91 & 0.94 & 0.89 & 0.93 & 0.96 & 0.92 \\
\hline \multirow[t]{2}{*}{ FM* } & 1.0 & 1.0 & 1.0 & 1.0 & 1.0 & 1.0 & | 1.0 & 1.0 & 1.0 & 1.0 & 1.0 & 1.0 \\
\hline & \multicolumn{3}{|c|}{ SRP142 } & \multicolumn{3}{|c|}{ ET336 } & & & \multicolumn{3}{|c|}{ Olivine- SPR 138} & \\
\hline wt\% & A1p9 & A3p1 & A3p9 & A1p3 & A6p1 & A6p4 & wt\% & A1p1 & A2p2 & A2p4 & A7p1 & A9p1 \\
\hline $\mathrm{SiO} 2$ & 52.5 & 53.7 & 52.3 & 53.3 & 52.4 & 52.6 & | SiO2 & 32.5 & 32.7 & 32.6 & 33.5 & 33.1 \\
\hline $\mathrm{Al}_{2} \mathrm{O}_{3}$ & 0.32 & 0.23 & 0.29 & 0 & 0.16 & 0.12 & | MgO & 13.6 & 11.5 & 11.2 & 16.2 & 14.2 \\
\hline $\mathrm{MgO}$ & 13.3 & 16.1 & 11.6 & 12.4 & 11.4 & 11.1 & $\mathrm{MnO}$ & 1.92 & 2.15 & 2.07 & 1.32 & 2.22 \\
\hline $\mathrm{MnO}$ & 0.74 & 0 & 0.88 & 0.46 & 0.78 & 0.75 & | FeO & 51.1 & 53.5 & 54 & 48.6 & 50.3 \\
\hline $\mathrm{FeO}$ & 8.85 & 4.64 & 11 & 9 & 11.2 & 11.2 & $\mathrm{CaO}$ & 0.9 & 0.23 & 0.23 & 0.37 & 0.2 \\
\hline $\mathrm{CaO}$ & 24.3 & 25.3 & 23.9 & 24.8 & 24.1 & 24.2 & l:at/4 O & & & & & \\
\hline \multicolumn{2}{|c|}{ cat/60 } & & & & & & I Si & 1 & 1.01 & 1.01 & 1.01 & 1.01 \\
\hline $\mathrm{Si}$ & 2.0 & 2.0 & 2.0 & 2.0 & 2.0 & 2.0 & | Mg & 0.62 & 0.53 & 0.52 & 0.73 & 0.64 \\
\hline $\mathrm{Al}$ & 0.01 & 0.01 & 0.01 & 0 & 0.01 & 0.01 & I $\mathrm{Mn}$ & 0.05 & 0.06 & 0.05 & 0.03 & 0.06 \\
\hline $\mathrm{Mg}$ & 0.75 & 0.89 & 0.66 & 0.7 & 0.65 & 0.63 & $\mathrm{Fe}$ & 1.3 & 1.39 & 1.4 & 1.22 & 1.28 \\
\hline $\mathrm{Mn}$ & 0.02 & 0 & 0.03 & 0.01 & 0.03 & 0.02 & I Ca & 0.03 & 0.01 & 0.01 & 0.01 & 0.01 \\
\hline $\mathrm{Fe}$ & 0.28 & 0.14 & 0.35 & 0.28 & 0.36 & 0.36 & | FM* & 2.0 & 1.98 & 1.98 & 1.99 & 1.99 \\
\hline $\mathrm{Ca}$ & 1.0 & 1.0 & 1.0 & 1.0 & 1.0 & 1.0 & $\% \mathrm{Fa}$ & 69 & 73 & 74 & 63 & 67 \\
\hline $\mathrm{FM}^{*}$ & 1.0 & 1.0 & 1.0 & 1.0 & 1.0 & 1.0 & & & & & & \\
\hline $\mathrm{FM}^{*}=$ & . & A & & & & & & & & & & \\
\hline
\end{tabular}


Table A2. Representative Analyses of oxide minerals.

\begin{tabular}{|c|c|c|c|c|c|c|c|c|c|c|c|c|c|}
\hline & \multicolumn{13}{|c|}{ Magnetite solid solution } \\
\hline & \multicolumn{3}{|c|}{ RN373 } & \multicolumn{3}{|c|}{ SPR142 } & \multicolumn{2}{|c|}{ ET336 } & \multicolumn{2}{|r|}{ SPR138 } & \multicolumn{3}{|c|}{ RN361 } \\
\hline wt\% & A7p4 & A7p6 & A12p4 & | A1p5 & A2p4 & A3p5 | & | A6p1 & A6p4 & A10p7 & A10p9 & A2p9 & A2p1 & A2p7 \\
\hline $\mathrm{Al}_{2} \mathrm{O}_{3}$ & 0.74 & 0.68 & 1.59 & 0.35 & 0.4 & $0.39 \mid$ & 0.07 & 0.09 & 2.34 & 3.06 & $1.39 \mid$ & 2.18 & 1.96 \\
\hline $\mathrm{TiO}_{2}$ & 12.7 & 15.1 & $11.7 \mid$ & 4.25 & 1.37 & 7.36 & 0.97 & 1.00 & 9.77 & 15.16 & 4.95 & | 13 & 9.39 \\
\hline $\mathrm{V}_{2} \mathrm{O}_{3}$ & & & । & | & & & 0.66 & 0.85 & & & & | & \\
\hline $\mathrm{Cr}_{2} \mathrm{O}_{3}$ & & & & 0.95 & 1.02 & $10.5 \mid$ & 0.67 & 0.55 & & & & | & \\
\hline MnO & 2.38 & 2.37 & $2.11 \mid$ & 0.57 & 0 & 0.93 & 0 & $0 \quad \mid$ & | 0.713 & 1.03 & 0.831 & | 1.25 & 0.96 \\
\hline $\mathrm{FeO}$ & 39.9 & 42.1 & $40.1 \mid$ & | 35.2 & 32.7 & 37.5 & | 31.9 & 31.8 & | 38.7 & 44.7 & 34.81 & | 42.1 & 39.8 \\
\hline $\mathrm{Fe}_{2} \mathrm{O}_{3}$ & 44.3 & 39.8 & $44.5 \mid$ & 58.7 & 64.5 & 43.3 & 65.8 & 65.7 & 48.5 & 36.0 & $58 \mid$ & 41.5 & 47.9 \\
\hline \multicolumn{2}{|c|}{ cat/4 O } & & I & & & I & | & & & & & | & \\
\hline Al & 0.03 & 0.03 & $0.07 \mid$ & 0.02 & 0.02 & $0.02 \mid$ & | 0.003 & 0.004 & 0.103 & 0.13 & $0.06 \mid$ & | 0.1 & 0.09 \\
\hline $\mathrm{Ti}$ & 0.36 & 0.43 & $0.33 \mid$ & 0.12 & 0.04 & 0.21 & 0.03 & 0.03 & | 0.276 & 0.43 & $0.14 \mid$ & 0.37 & 0.27 \\
\hline V & & & I & | & & & | 0.02 & 0.02 & & & & | & \\
\hline $\mathrm{Cr}$ & & & & 0.03 & 0.03 & $0.32 \mid$ & | 0.02 & 0.02 & & & & | & \\
\hline $\mathrm{Mn}$ & 0.08 & 0.08 & $0.07 \mid$ & 0.02 & 0 & $0.03 \mid$ & 0 & 0 & 0.02 & 0.032 & 0.031 & | 0.04 & 0.03 \\
\hline $\mathrm{Fe} 2+$ & 1.3 & 1.3 & 1.3 & 1.13 & 1.05 & $1.19 \mid$ & 1.0 & 1.0 & 1.22 & 1.40 & $1.11 \mid$ & | 1.32 & 1.26 \\
\hline $\mathrm{Fe} 3+$ & 1.3 & 1.1 & 1.3 & 1.69 & 1.87 & 1.24 & 1.9 & 1.9 & 1.37 & 1.01 & 1.66 & | 1.17 & 1.36 \\
\hline \multirow[t]{4}{*}{ \%ulv } & 36 & 43 & 331 & 12 & 4 & 21 & 2.8 & 2.9 & 28 & 43 & 14 & | 37 & 27 \\
\hline & & & & & & & & & & & & & \\
\hline & \multicolumn{13}{|c|}{ Ilmenite solid solution } \\
\hline & \multicolumn{3}{|c|}{ RN373 } & \multicolumn{3}{|c|}{ SPR142 } & \multicolumn{2}{|c|}{ ET336 } & \multicolumn{3}{|c|}{ SPR138 } & \multicolumn{2}{|c|}{ RN361 } \\
\hline wt\% & A7p3 & A7p8 & A12pe & | A1p3 & A2p6 & A3p2 | & A6p5 & A6p7 & |A10p2 & A10p4 & A2p7 & | A2p8 & A2p9 \\
\hline $\mathrm{MgO}$ & 0.46 & 0.23 & 0.3 & 0.21 & 0.17 & $\begin{array}{ll}0 & 1\end{array}$ & 0.16 & 0.27 & | 0.32 & 0.26 & 0.39 & & \\
\hline $\mathrm{TiO}_{2}$ & 49.7 & 49.5 & $49.3 \mid$ & | 48.2 & 49.5 & 47.7 & 49.3 & 49.6 & 50.1 & 49.6 & $49.8 \mid$ & | 49.2 & 49.8 \\
\hline $\mathrm{MnO}$ & 5.47 & 4.59 & 2.89 & 2.24 & 1.7 & $1.49 \mid$ & 2.57 & 2.28 & 1.07 & 1.29 & 0.9 & | 1.67 & 1.6 \\
\hline $\mathrm{FeO}$ & 39.5 & 39.2 & $42.3 \mid$ & 42.8 & 43.3 & $42.5 \mid$ & 42.7 & 42.6 & 43.2 & 42.9 & 43.5 & | 44.7 & 44.3 \\
\hline $\mathrm{Fe}_{2} \mathrm{O}_{3}$ & 4.88 & 6.51 & $5.22 \mid$ & 6.49 & 5.35 & $8.34 \mid$ & 5.27 & 5.26 & 5.33 & 5.90 & $5.37 \mid$ & | 3.74 & 3.7 \\
\hline \multirow{2}{*}{\multicolumn{2}{|c|}{$\begin{array}{l}\mathrm{Nb}_{2} \mathrm{O}_{5} \\
\mathrm{cat} / 3 \mathrm{O}\end{array}$}} & & I & & & I & | & & | & & & | 0.78 & 0.58 \\
\hline & & & 1 & & & I & 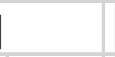 & & & & & | & \\
\hline $\mathrm{Mg}$ & 0.02 & 0.01 & $0.01 \mid$ & | 0.01 & 0.01 & 0 & 0.01 & 0.01 & | 0.012 & 0.01 & $0.01 \mid$ & & \\
\hline $\mathrm{Ti}$ & 0.94 & 0.94 & $0.94 \mid$ & | 0.92 & 0.94 & $0.91 \mid$ & 0.94 & 0.94 & | 0.95 & 0.94 & $0.95 \mid$ & | 0.94 & 0.95 \\
\hline $\mathrm{Mn}$ & 0.12 & 0.1 & $0.06 \mid$ & 0.05 & 0.04 & $0.03 \mid$ & 0.06 & 0.05 & | 0.023 & 0.028 & 0.02 & | 0.04 & 0.03 \\
\hline $\mathrm{Fe} 2+$ & 0.84 & 0.83 & 0.9 & 0.91 & 0.92 & 0.9 & 0.91 & 0.9 & | 0.91 & 0.91 & 0.92 & | 0.95 & 0.94 \\
\hline $\mathrm{Fe} 3+$ & 0.09 & 0.12 & $0.1 \mid$ & | 0.12 & 0.1 & 0.16 & 0.1 & 0.1 & 0.10 & 0.11 & $0.10 \mid$ & | 0.07 & 0.07 \\
\hline $\mathrm{Nb}$ & & & I & & & | & | & & & & & | 0.01 & 0.01 \\
\hline \%ilm & 94 & 94 & 94 | & 92 & 94 & 91 । & | 93.7 & 94.1 & 95.2 & 94.3 & 94.6 | & | 94 & 95 \\
\hline$u l v=\iota$ & vosp & 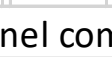 & ponent & t; ilm = & 1 & & & & & & & & \\
\hline
\end{tabular}


Table A3. Representative Analyses of Amphiboles.

\begin{tabular}{|c|c|c|c|c|c|c|c|c|c|c|c|c|c|}
\hline & \multicolumn{6}{|c|}{ RN373 } & \multicolumn{6}{|c|}{ RN377 } & \\
\hline wt\% & A1p6 & A4p23 & A4p9 & A5p3 & A5p5 & A9p9| & |A2p4 & $A 2 p 6$ & A2p8 & $A 2 p 7$ & A2p9 & A4p6 & \\
\hline $\mathrm{SiO}_{2}$ & 42.7 & 44.5 & 43.1 & 41.6 & 42.8 & 43.7 | & | 41.6 & 41.4 & 41.6 & 38.3 & 41.1 & 41.1 & \\
\hline $\mathrm{Al}_{2} \mathrm{O}_{3}$ & 12.5 & 12.1 & 12.9 & 12.9 & 13.2 & 10.7 & 11 & 12.2 & 12.5 & 14.0 & 12.9 & 12.1 & \\
\hline $\mathrm{TiO}_{2}$ & 2.58 & 2.1 & 2.16 & 0.13 & 0.22 & 0.13 & 1.66 & 2.14 & 0.71 & 0.20 & 0.07 & 0.57 & \\
\hline $\mathrm{MgO}$ & 6.69 & 6.78 & 6.98 & 4.54 & 4.68 & 6.1 & 6.69 & 6.85 & 7.17 & 1.94 & 2.27 & 3.95 & \\
\hline $\mathrm{MnO}$ & 0.91 & 0.89 & 0.82 & 1.13 & 0.79 & $1.39 \mid$ & 1.39 & 1.26 & 1.21 & 1.84 & 1.35 & 1.64 & \\
\hline $\mathrm{FeO}$ & 22.5 & 22.6 & 21.4 & 27.6 & 26.3 & $25.7 \mid$ & 25.9 & 24.4 & 24.5 & 31.6 & 30.6 & 28.3 & \\
\hline $\mathrm{CaO}$ & 12.1 & 11.1 & 12.6 & 12.2 & 12 & 12.4 & 11.7 & 11.7 & 12.3 & 12.1 & 11.7 & 12.4 & \\
\hline $\mathrm{Na}_{2} \mathrm{O}$ & 2.83 & 3.22 & 2.17 & 1.42 & 1.59 & 1.45 & 2.23 & 1.52 & 2.3 & 1.79 & 1.53 & 2.10 & \\
\hline $\mathrm{K}_{2} \mathrm{O}$ & 1.83 & 2.1 & 1.88 & 2.59 & 1.98 & 1.88 & 1.87 & 1.95 & 1.81 & 2.81 & 2.55 & 1.78 & \\
\hline $\mathrm{Cl}$ & 0.19 & 0.27 & 0.22 & 2.06 & 1.79 & 1.39 & 0.57 & 0.36 & 0.75 & 4.0 & 3.3 & 2.6 & \\
\hline \multicolumn{14}{|c|}{ ions/230 } \\
\hline $\mathrm{Si}$ & 6.22 & 6.41 & 6.27 & 6.25 & 6.37 & 6.53 & 6.22 & 6.16 & 6.17 & 5.91 & 6.27 & 6.22 & \\
\hline $\mathrm{Al}$ & 2.15 & 2.05 & 2.21 & 2.29 & 2.32 & 1.88 & 1.95 & 2.15 & 2.18 & 2.54 & 2.32 & 2.17 & \\
\hline $\mathrm{Ti}$ & 0.28 & 0.23 & 0.24 & 0.01 & 0.02 & 0.01 & 0.19 & 0.24 & 0.08 & 0.023 & 0.01 & 0.07 & \\
\hline $\mathrm{Mg}$ & 1.45 & 1.46 & 1.51 & 1.02 & 1.04 & 1.36 & 1.49 & 1.52 & 1.59 & 0.45 & 0.52 & 89 & \\
\hline $\mathrm{Mn}$ & 0.11 & 0.11 & 0.1 & 0.14 & 0.1 & 0.18 & 0.18 & 0.16 & 0.15 & 0.24 & 0.17 & 0.21 & \\
\hline $\mathrm{Fe}$ & 2.74 & 2.73 & 2.61 & 3.47 & 3.27 & 3.2 & 3.24 & 3.03 & 3.04 & 4.08 & 3.9 & 3.59 & \\
\hline $\mathrm{Ca}$ & 1.89 & 1.71 & 1.96 & 1.96 & 1.9 & 1.98 & 1.87 & 1.86 & 1.96 & 2.00 & 1.91 & 2.01 & \\
\hline $\mathrm{Na}$ & 0.8 & 9 & 0.61 & 0.41 & 0.46 & 0.42 & 0.64 & 0.44 & 0.66 & 0.54 & 0.45 & 0.62 & \\
\hline $\mathrm{K}$ & 0.34 & 0.39 & 0.35 & 0.5 & 0.38 & 0.36 & 0.36 & 0.37 & 0.34 & 0.55 & 0.5 & 0.34 & \\
\hline \multirow[t]{2}{*}{$\mathrm{Cl}$} & 0.05 & 0.07 & 0.05 & 0.53 & 0.45 & 0.35 & 0.14 & 0.09 & 0.19 & 1.05 & 0.86 & 0.68 & \\
\hline & \multicolumn{3}{|c|}{ RN368 } & \multicolumn{3}{|c|}{ AW321 } & \multicolumn{3}{|c|}{ SPR138 } & \multicolumn{3}{|c|}{ orthoamphibole } & \\
\hline$w t \%$ & A1p7 & A1p9 & A2p7 & | A1p4 & A2p5 & A2p9| & |A5p1 & A5p9 & A7p6 & wt\% & A14p1 & A4p7 & A4p15 \\
\hline $\mathrm{SiO}_{2}$ & 55.5 & 51.1 & 50.6 & \begin{tabular}{|l|}
47.7 \\
\end{tabular} & 47.3 & 47.2 & 43.4 & 44.1 & 42.5 & $\mathrm{SiO}_{2}$ & 56.6 & 55.6 & \\
\hline $\mathrm{Al}_{2} \mathrm{O}_{3}$ & 1.24 & 5.88 & 5.99 & 8.07 & 8.59 & 8.8 & 13.4 & 14.4 & 13.1 & & & & \\
\hline $\mathrm{TiO}_{2}$ & 0.33 & 1.44 & 1.68 & 1.95 & 1.82 & 1.79 & 2.84 & 2.71 & 2.85 & & & & \\
\hline $\mathrm{MgO}$ & 14.6 & 13.3 & 13.5 & 10.7 & 10.6 & $11.4 \mid$ & 9.42 & 9.75 & $9.42 \mid$ & $\mathrm{MgO}$ & 19.9 & 16.9 & 17.4 \\
\hline $\mathrm{MnO}$ & 0.55 & 0.46 & 0.73 & 1.34 & 1.21 & 1.36 & 0.43 & 0.36 & 0.41 & $\mathrm{MnO}$ & 1.19 & 1.72 & 1.91 \\
\hline $\mathrm{FeO}$ & 15.1 & 16.3 & 17.9 & 17.7 & 18.1 & $17.4 \mid$ & 18.3 & 17.1 & 201 & $\mathrm{FeO}$ & 20.6 & 23.6 & 24.1 \\
\hline $\mathrm{CaO}$ & 12.6 & 11.5 & 11.3 & 12.6 & 12.3 & $12.1 \mid$ & 12.2 & 11.6 & $11.7 \mid$ & $\mathrm{CaO}$ & 1.73 & 2.18 & 1.11 \\
\hline $\mathrm{Na}_{2} \mathrm{O}$ & 0.76 & 2.53 & $2.53 \mid$ & 1.48 & 1.6 & $3.39 \mid$ & 2.43 & 2.86 & $2.72 \mid$ & & & & \\
\hline $\mathrm{K}_{2} \mathrm{O}$ & 0.43 & 0.68 & 0.88 & 1.48 & 1.41 & $1.67 \mid$ & 1.91 & 1.9 & $2.03 \mid$ & & 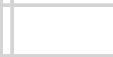 & | & \\
\hline $\mathrm{Cl}$ & 0.06 & 0.25 & 0.25 & 0.36 & 0.28 & 0.35 & 0.25 & 0.25 & $0.24 \mid$ & & SRP14 & \multicolumn{2}{|c|}{ ET226 } \\
\hline \multicolumn{2}{|c|}{ ions/230 } & & & & & & & & & \multicolumn{2}{|c|}{ ions $/ 230$} & & \\
\hline $\mathrm{Si}$ & 7.83 & 7.17 & $7.11 \mid$ & 6.84 & 6.79 & $6.68 \mid$ & | 6.2 & 6.22 & 5.99 & $\mathrm{Si}$ & 8.0 & 8.0 & 8.0 \\
\hline $\mathrm{Al}$ & 0.21 & 0.97 & 0.99 & 1.36 & 1.45 & $1.47 \mid$ & 2.25 & 2.38 & 2.17 & & & & \\
\hline $\mathrm{Ti}$ & 0.03 & 0.15 & 0.18 & 0.21 & 0.2 & 0.19 & 0.3 & 0.29 & 0.31 & & & & \\
\hline $\mathrm{Mg}$ & 3.07 & 2.78 & 2.82 & 2.3 & 2.28 & 2.4 & 2.00 & 2.05 & 1.98 & $\mathrm{Mg}$ & 4.18 & 3.63 & \\
\hline $\mathrm{Mn}$ & 0.07 & 0.06 & 0.09 & 0.16 & 0.15 & 0.16 & 0.05 & 0.04 & 0.05 & $\mathrm{Mn}$ & 0.14 & 0.21 & 0.23 \\
\hline $\mathrm{Fe}$ & 1.79 & 1.92 & 2.11 & 2.12 & 2.17 & 2.06 & 2.18 & 2.02 & 2.36 & $\mathrm{Fe}$ & 2.44 & 2.84 & 2.89 \\
\hline $\mathrm{Ca}$ & 1.91 & 1.73 & $1.7 \mid$ & 1.93 & 1.9 & $1.83 \mid$ & | 1.87 & 1.74 & 1.76 & $\mathrm{Ca}$ & 0.26 & | 0.34 & 0.17 \\
\hline $\mathrm{Na}$ & 0.21 & 0.69 & 0.69 & 0.41 & 0.45 & $0.93 \mid$ & 0.67 & 0.78 & 0.74 & & & & \\
\hline$K$ & 0.08 & 0.12 & 0.16 & 0.27 & 0.26 & 0.3 & 0.35 & 0.34 & 0.37 & & & & \\
\hline $\mathrm{Cl}$ & 0.02 & 0.06 & 0.06 & 0.09 & 0.07 & 0.08 & 0.06 & 0.06 & 0.06 & & & & \\
\hline
\end{tabular}


Table A4. Representative Biotite Analyses.

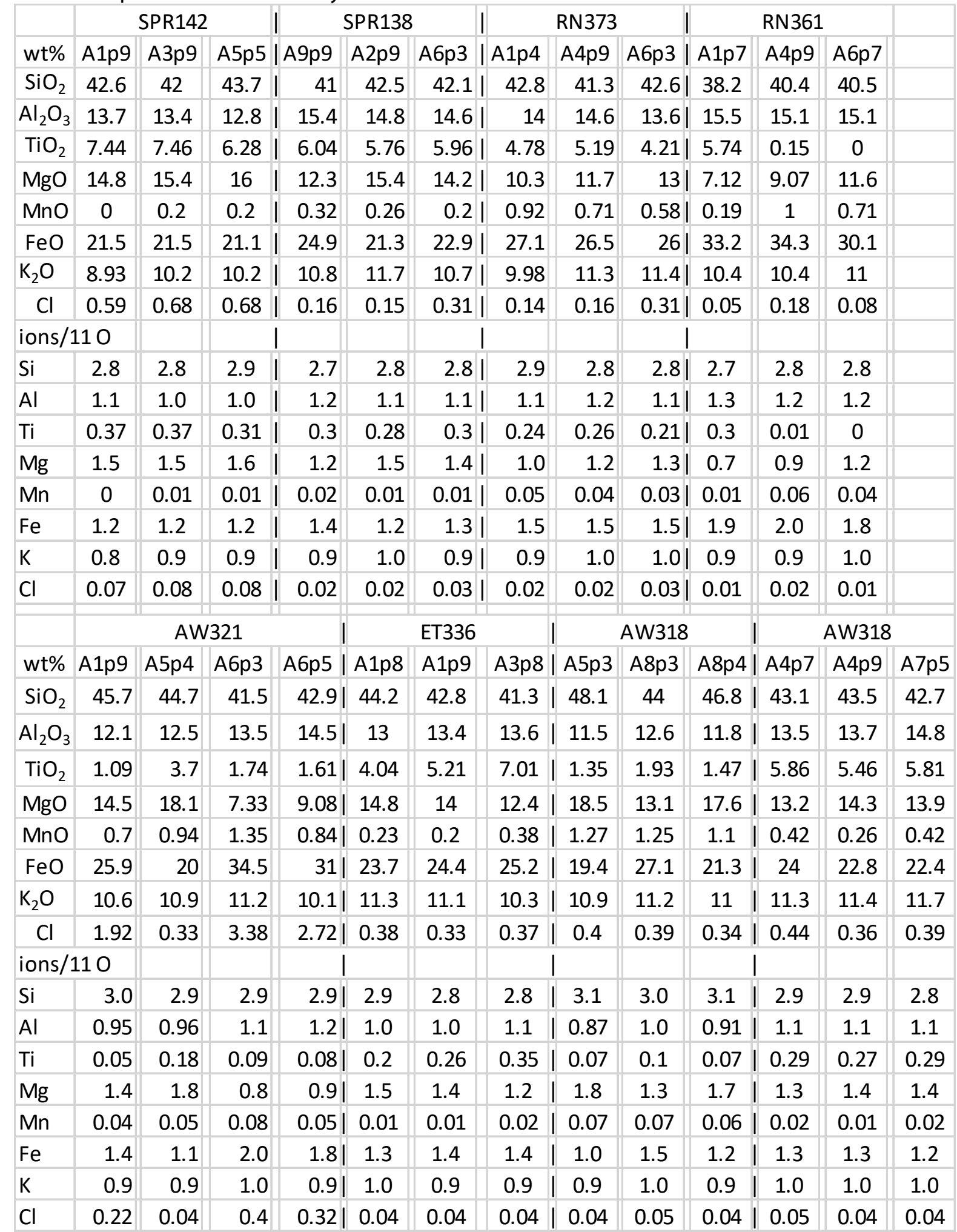


Table A5. Representative Chlorite Analyses.

\begin{tabular}{|c|c|c|c|c|c|c|c|c|c|}
\hline \multirow[b]{2}{*}{ wt\% } & \multicolumn{3}{|c|}{ RN368 } & \multicolumn{3}{|c|}{ SPR142 } & \multicolumn{3}{|c|}{ I $\quad$ ET366 } \\
\hline & A1p9 & A2p4 & A2p6 & I A5p6 & A6p8 & A5p7 & A1p1 & A1p4 & A6p7 \\
\hline $\mathrm{SiO}_{2}$ & 30.9 & 30.6 & 30.6 & | 31.7 & 30.3 & $30.3 \mid$ & | 35.1 & 35.71 & 37.9 \\
\hline $\mathrm{Al}_{2} \mathrm{O}_{3}$ & 21.2 & 20.6 & 17.8 & | 21 & 20.8 & 21.5 & 21.5 & 26.11 & 18.5 \\
\hline $\mathrm{MgO}$ & 18.7 & 19.1 & 20.74 & 19.7 & 17.8 & $17.7 \mid$ & 19.6 & 16.32 & 17.2 \\
\hline $\mathrm{MnO}$ & 0.88 & 0.85 & 0.414 & 0.28 & 0.52 & $0.7 \mid$ & 0.15 & .343 & 0.14 \\
\hline $\mathrm{FeO}$ & 28.4 & 28.7 & 30.45 & | 27.3 & 30.5 & $29.8 \mid$ & 23.6 & 51 & 26.3 \\
\hline \multicolumn{2}{|c|}{ ions/14 O } & & & I & & I & | & & \\
\hline $\mathrm{Si}$ & 2.85 & 2.84 & 2.867 & 2.9 & 2.8 & $2.8 \mid$ & 3.1 & 3.1 & 3.4 \\
\hline Al & 31 & 2.25 & 1.966 & 2.26 & 2.3 & $2.4 \mid$ & 2.3 & 2.7 & 2.0 \\
\hline M & 2.57 & 2.64 & 2.898 & 2.69 & 2.5 & 2.51 & 2.6 & 27 & 2.3 \\
\hline & 07 & 0.07 & .033 & 0.02 & 0.04 & 0.05 & | 0.01 & & 0.01 \\
\hline $\mathrm{Fe}$ & & & .4 & & & 1 & 1.8 & & 0 \\
\hline \multirow[t]{2}{*}{ Mg\# } & 0.53 & 0.54 & 0.545 & 0.56 & 0.51 & $0.51 \mid$ & 0.6 & 1 & 0.54 \\
\hline & \multicolumn{3}{|c|}{ RN373 } & \multicolumn{3}{|c|}{ RN361 } & \multicolumn{3}{|c|}{ AW318 } \\
\hline wt $\%$ & A6p1 & A9p7 & A14p1 & A6p4 & A7p2 & A7p5 & | A1p1 & A11p6 & A6p4 \\
\hline $\mathrm{SiO}_{2}$ & 31.7 & 32.3 & 31.0 & | 33.5 & 32 & 31.5 & | 39.6 & 36.8 & 36.8 \\
\hline $\mathrm{Al}_{2} \mathrm{O}_{3}$ & 18.6 & 20.2 & 19.9 & 1 22 & 21.5 & $20 \mid$ & 23.1 & 18.4 & 20.0 \\
\hline $\mathrm{TiO}_{2}$ & & & & | & & & 1.87 & 0.66 & 2.01 \\
\hline $\mathrm{MgO}$ & 14.6 & 1.4 & .6 & | 7.55 & 84 & 81 & 5.35 & 3.06 & 5.27 \\
\hline $\mathrm{MnO}$ & & & 18 & | 1.43 & 1.28 & $2.11 \mid$ & & & \\
\hline $\mathrm{FeO}$ & 33.9 & 34.8 & 37.4 & | 35.5 & 36.4 & $39.9 \mid$ & | 30.1 & & 35.9 \\
\hline \multicolumn{2}{|c|}{ ions/140 } & & & I & & & & & \\
\hline $\mathrm{Si}$ & 3.01 & 3.06 & 99 & | 3.16 & 3.05 & $3.08 \mid$ & 3.55 & 3.53 & 3.43 \\
\hline Al & 2.09 & 2.26 & 2.26 & | 2.45 & 2.42 & $2.31 \mid$ & 2.45 & 2.08 & 2.21 \\
\hline $\mathrm{Ti}$ & & & & & & & 0.13 & 0.05 & 0.14 \\
\hline $\mathrm{Mg}$ & & & & & 1.26 & $0.93 \mid$ & 0.72 & 0.44 & 0.73 \\
\hline $\mathrm{Mn}$ & 0.09 & 0.11 & 0.10 & | 0.12 & 0.1 & $0.17 \mid$ & & & \\
\hline $\mathrm{Fe}$ & & & & | 2.8 & 2.9 & 3.31 & | 2.3 & 3.3 & 2.8 \\
\hline Mg\# & 0.43 & 0.36 & 0.33 & | 0.27 & 0.29 & $0.21 \mid$ & | 0.24 & 0.12 & 0.21 \\
\hline IVIS" & & & & & & & & & \\
\hline
\end{tabular}


Table A6. Representative Feldspar Analyses.

\begin{tabular}{|c|c|c|c|c|c|c|c|c|c|c|c|c|}
\hline \multirow[b]{3}{*}{ wt\% } & \multicolumn{12}{|c|}{ Plagioclase feldspar } \\
\hline & \multicolumn{3}{|c|}{ SPR138 } & | & \multicolumn{2}{|c|}{ RN373 } & 1 & \multicolumn{2}{|c|}{ AW318 } & । & \multicolumn{2}{|l|}{ ET336 } \\
\hline & A10p5 & A1p9 & A2p9 & | A4p31 & A13p2 & A15p9 & |A1p6 & A2p3 & A3p12 & |A1p12 & A1p15 & A2p13 \\
\hline $\mathrm{SiO}_{2}$ & 55.4 & 60.7 & 59.0 & 66.5 & 61.2 & 55.5 & | 69.4 & 69.0 & 68.8 & | 60.9 & 60.4 & 64.4 \\
\hline $\mathrm{Al}_{2} \mathrm{O}_{3}$ & 28.1 & 24.8 & 25.7 & | 20.7 & 24.2 & 28.5 & 18.8 & 19.1 & 19.3 & | 24.3 & 24.4 & 22.2 \\
\hline $\mathrm{Na}_{2} \mathrm{O}$ & 5.57 & 7.76 & 7.43 & | 10.27 & 8.06 & 5.54 & | 11.5 & 11.5 & 11.3 & | 8.0 & 7.4 & 9.3 \\
\hline $\mathrm{CaO}$ & 10.8 & 6.7 & 7.9 & | 2.6 & 6.5 & 10.5 & 0.36 & 0.47 & 0.55 & | 6.8 & 7.8 & 4.1 \\
\hline \multicolumn{2}{|c|}{ cat/80 } & & & | & & & | & & & | & & \\
\hline Si & 2.5 & 2.7 & 2.6 & 2.9 & 2.7 & 2.5 & 3.0 & 3.0 & 3.0 & | 2.7 & 2.7 & 2.8 \\
\hline $\mathrm{Al}$ & 1.5 & 1.3 & 1.4 & 1.1 & 1.3 & 1.5 & | 1.0 & 1.0 & 1.0 & | 1.3 & 1.3 & 1.2 \\
\hline $\mathrm{Na}$ & 0.49 & 0.67 & 0.64 & | 0.87 & 0.69 & 0.48 & | 0.97 & 0.97 & 0.96 & | 0.69 & 0.64 & 0.80 \\
\hline $\mathrm{Ca}$ & 0.52 & 0.32 & 0.38 & 0.12 & 0.31 & 0.51 & | 0.02 & 0.02 & 0.03 & | 0.32 & 0.37 & 0.19 \\
\hline \multirow[t]{4}{*}{$\% A n$} & 52 & 32 & 37 & | 12 & 31 & 51 & 2 & 2 & 3 & | 32 & 37 & 19 \\
\hline & & & & & & & & & & & & \\
\hline & \multicolumn{12}{|c|}{ Alkali feldspar } \\
\hline & \multicolumn{3}{|c|}{ RN361 } & \multicolumn{3}{|c|}{ SPR138 } & \multicolumn{3}{|c|}{ | SPR142 } & \multicolumn{3}{|c|}{ RN368 } \\
\hline wt\% & A1p10 & A6p9 & A6p13 & | A1p14 & $A 2 p 11$ & A12p1 & A1p19 & 9 A1p5 & A6p13 & |A1p21 & A2p15 & A4p16 \\
\hline $\mathrm{SiO}_{2}$ & 64.9 & 65.3 & 64.5 & | 64.7 & 65.9 & 64.2 & | 66.0 & 65.2 & 64.3 & | 65.6 & 65.9 & 65.8 \\
\hline $\mathrm{Al}_{2} \mathrm{O}_{3}$ & 18.4 & 18.8 & 19.1 & | 19.0 & 18.5 & 19.0 & | 18.3 & 18.9 & 18.8 & | 18.6 & 18.3 & 18.3 \\
\hline $\mathrm{Na}_{2} \mathrm{O}$ & 3.96 & 3.70 & 4.32 & 3.40 & 3.07 & 3.54 & | 1.87 & 1.56 & 1.74 & | 2.53 & 1.71 & 2.07 \\
\hline $\mathrm{K}_{2} \mathrm{O}$ & 10.1 & 11.2 & 9.1 & | 11.5 & 12.3 & 10.5 & 13.5 & 13.9 & 14.1 & | 13.3 & 14.1 & 13.8 \\
\hline $\mathrm{BaO}$ & 2.62 & 1.01 & 2.92 & | 1.37 & 0.16 & 2.73 & | 0.36 & 0.50 & 1.14 & | & & \\
\hline \multicolumn{2}{|c|}{$\mathrm{cat} / 8 \mathrm{O}$} & & & I & & & I & & & | & & \\
\hline Si & 3.0 & 3.0 & 3.0 & 3.0 & 3.0 & 3.0 & 3.0 & 3.0 & 3.0 & | 3.0 & 3.0 & 3.0 \\
\hline $\mathrm{Al}$ & 1.0 & 1.0 & 1.0 & | 1.0 & 1.0 & 1.0 & | 1.0 & 1.0 & 1.0 & | 1.0 & 1.0 & 1.0 \\
\hline $\mathrm{Na}$ & 0.35 & 0.33 & 0.39 & | 0.30 & 0.27 & 0.32 & | 0.17 & 0.14 & 0.16 & | 0.22 & 0.15 & 0.18 \\
\hline K & 0.59 & 0.65 & 0.54 & 0.67 & 0.72 & 0.62 & 0.79 & 0.81 & 0.83 & | 0.77 & 0.82 & 0.81 \\
\hline $\mathrm{Ba}$ & 0.047 & 0.018 & 0.053 & | 0.025 & 0.003 & 0.049 & | 0.006 & 0.01 & 0.021 & | & & \\
\hline$\% O r$ & 60 & 65 & 55 & | 67 & 72 & 63 & 1 82 & 85 & 82 & 1 77 & 84 & 81 \\
\hline$\% \mathrm{Cs}$ & 5.0 & 1.8 & 5.7 & 2.5 & 0.3 & 5.3 & 0.7 & 1.0 & 2.1 & I & & \\
\hline$A n=$ & arth & $1 C_{0}$ & $2-2<-81$ & - & & & 1. & & 年 & $\left.\mathrm{I}_{2} \mathrm{Si}_{2} \mathrm{O}_{8}\right)$ & & \\
\hline
\end{tabular}


Table A7. Representative Apatite Analyses.

\begin{tabular}{|c|c|c|c|c|c|c|c|c|c|c|}
\hline \multirow[b]{2}{*}{ wt\% } & \multicolumn{3}{|c|}{ AW318 } & & \multicolumn{3}{|c|}{ RN368 } & \multicolumn{3}{|c|}{ RN373 } \\
\hline & A1p7 & A8p1 & A12p2 & & A6p9 & A9p1 & A9p2 & | A1p1 & A4p2 & A4p3 \\
\hline $\mathrm{P}_{2} \mathrm{O}_{5}$ & 39.8 & 39.3 & 39.9 & & 40.8 & 41.3 & 41.0 & 40.6 & 40.3 & 39.5 \\
\hline $\mathrm{SiO}_{2}$ & 1.36 & 1.39 & 1.53 & & 0.43 & 0.32 & 0.47 & | 1.07 & 0.63 & 1.1 \\
\hline $\mathrm{CaO}$ & 53.1 & 3.1 & 3.4 & & 53.4 & 54.4 & 54.1 & 54.2 & 53.1 & \\
\hline $\mathrm{Ce}_{2} \mathrm{O}_{3}$ & & & & & 0.83 & & 0.95 & 2.04 & & \\
\hline $\mathrm{La}_{2} \mathrm{O}_{3}$ & 0.8 & & .1 & & 0.69 & & 49 & 0.52 & 0.63 & 97 \\
\hline $\mathrm{F}$ & 3.18 & 1.8 & 57 & & 3.33 & & 82 & 1.44 & 3.74 & \\
\hline $\mathrm{Cl}$ & & & & & 17 & & 18 & & 0.08 & \\
\hline \multicolumn{2}{|c|}{ ion/250 } & & & & & & & & & \\
\hline$P$ & 5.8 & & & & 5.9 & & .9 & 5.8 & 5.9 & \\
\hline $\mathrm{SiO} 2$ & 0.23 & & 26 & & 0.07 & .05 & .08 & 0.18 & 0.11 & \\
\hline $\mathrm{Ca}$ & & & & & .8 & & & & & \\
\hline $\mathrm{Ce}$ & 11 & 18 & 15 & & 0.05 & .05 & .06 & 0.13 & 0.09 & .09 \\
\hline La & & & & & 04 & & 03 & & 0.04 & \\
\hline $\mathrm{F}$ & & & & & & & & & & \\
\hline \multirow[t]{3}{*}{$\mathrm{Cl}$} & & & & & 05 & & 05 & .03 & 0.02 & 4 \\
\hline & \multirow{2}{*}{\multicolumn{3}{|c|}{ SPR138 }} & & \multirow{2}{*}{\multicolumn{3}{|c|}{ SPR142 }} & \multirow{2}{*}{\multicolumn{3}{|c|}{ RN377 }} \\
\hline & & & & & & & & & & \\
\hline wt\% & A1p5 & A1p8 & A4p6 & & A1p9 & A3p9 & A5p2 & | A2p13 & A6p3 & A9p6 \\
\hline $\mathrm{P}_{2} \mathrm{O}_{5}$ & 41.7 & 40.3 & & & 41.4 & 1.2 & 1.5 & 40.2 & 41.0 & .1 \\
\hline $\mathrm{SiO}_{2}$ & 0.33 & & .34 & & 0.44 & .85 & .62 & 1.06 & 0.49 & \\
\hline $\mathrm{CaO}$ & 55.1 & & & & 54.6 & & 5.1 & & 54.1 & \\
\hline $\mathrm{Ce}_{2} \mathrm{O}_{3}$ & 0.43 & 0.81 & & & 0.58 & .62 & 1.39 & 2.02 & 1.46 & 2.23 \\
\hline $\mathrm{F}$ & 2.09 & & & & & & & .76 & 2.68 & \\
\hline $\mathrm{Cl}$ & 0.33 & & 0.33 & & & & 0.58 & 0.16 & 0.12 & \\
\hline \multicolumn{2}{|c|}{ ion/250 } & & & & & & & & & \\
\hline$P$ & & & & & & & & & 9 & \\
\hline $\mathrm{SiO} 2$ & & & & & & & & | 0.2 & 0.1 & \\
\hline $\mathrm{Ca}$ & & & & & & & .94 & | 9.88 & 9.94 & \\
\hline $\mathrm{Ce}$ & 0.03 & 0.05 & & & 0.04 & & 0.09 & 0.13 & 0.09 & 0.14 \\
\hline $\mathrm{F}$ & & & & & & & & & & \\
\hline $\mathrm{Cl}$ & 0.09 & 0.09 & 0.10 & & 0.17 & 0.18 & 0.17 & | 0.05 & 0.03 & 0.05 \\
\hline
\end{tabular}


Table A8. Representative Titanite Analyses.

\begin{tabular}{|c|c|c|c|c|c|c|c|c|c|c|c|c|}
\hline & & RN377 & & & RN361 & & & RN368 & & & RN377 & \\
\hline & A3p2 & $A 2 p 3$ & A8p6 | & |A5ap2 & A5ap5 & $A 5 b p 1$ & A1p3 & A1p6 & A4p6 & | A3p2 & A2p3 & A8p6 \\
\hline $\mathrm{SiO}_{2}$ & 30.5 & 30.0 & 30.2 & | 30.6 & 31.4 & 30.7 & 30.5 & 30.2 & 30.7 & | 30.5 & 30.0 & 30.2 \\
\hline $\mathrm{Al}_{2} \mathrm{O}_{3}$ & 1.18 & 1.32 & $1.75 \mid$ & | 2.7 & 3.05 & 2.95 & 0.92 & 0.84 & 1.32 & | 1.18 & 1.32 & 1.75 \\
\hline $\mathrm{TiO}_{2}$ & 35.9 & 36.0 & 35.9 | & | 35.6 & 32.4 & 34.5 & | 37 & 37.8 & 37.2 & | 35.9 & 36.0 & 35.9 \\
\hline $\mathrm{FeO}$ & 2.19 & 2.84 & $2.17 \mid$ & | 1.45 & 3.07 & 1.98 & 1.82 & 1.2 & 1.08 & | 2.19 & 2.84 & 2.17 \\
\hline $\mathrm{CaO}$ & 26.9 & 26.9 & 27.8 & | 27.8 & 27.9 & 27.8 & | 27.4 & 27.4 & 27.7 & | 26.9 & 26.9 & 27.8 \\
\hline $\mathrm{Nb}_{2} \mathrm{O}_{5}$ & 0.59 & 0.35 & 0.36 & | 0.02 & 0.4 & 0.22 & 0.54 & 0.31 & 0.29 & | 0.59 & 0.35 & 0.36 \\
\hline $\mathrm{La}_{2} \mathrm{O}_{3}$ & 1.07 & 0.4 & 0.54 & | 0.77 & 0.57 & 0.43 & 0.95 & 0.88 & 0.74 & | 1.07 & 0.4 & 0.54 \\
\hline $\mathrm{Ce}_{2} \mathrm{O}_{3}$ & 0.97 & 0.43 & $0.36 \mid$ & | 0.28 & 0.23 & 0.34 & | 0.6 & 0.84 & 0.45 & | 0.97 & 0.43 & 0.36 \\
\hline $\mathrm{F}$ & 0.71 & 1.63 & 0.92 & $\begin{array}{lll}\mid & 0.77\end{array}$ & 0.95 & 1.08 & 0.32 & 0.5 & 0.64 & | 0.71 & 1.63 & 0.92 \\
\hline \multicolumn{2}{|c|}{ ion/4 Si } & & & & & & & & & & & \\
\hline $\mathrm{Si}$ & 4.0 & 4.0 & $4.0 \mid$ & 4.0 & 4.0 & 4.0 & | 4.0 & 4.0 & 4.0 & 4.0 & 4.0 & 4.0 \\
\hline Al & 0.18 & 0.21 & 0.27 & | 0.42 & 0.46 & 0.45 & 0.14 & 0.13 & 0.2 & | 0.18 & 0.21 & 0.27 \\
\hline $\mathrm{Ti}$ & 3.5 & 3.6 & 3.6 & 3.5 & 3.1 & 3.4 & 3.6 & 3.8 & 3.6 & 3.5 & 3.6 & 3.6 \\
\hline $\mathrm{Fe}$ & 0.24 & 0.32 & 0.24 & | 0.16 & 0.33 & 0.22 & | 0.2 & 0.13 & 0.12 & | 0.24 & 0.32 & 0.24 \\
\hline $\mathrm{Ca}$ & 3.8 & 3.8 & 3.9 & | 3.9 & 3.8 & 3.9 & | 3.8 & 3.9 & 3.9 & | 3.8 & 3.8 & 3.9 \\
\hline $\mathrm{Nb}$ & 0.04 & 0.02 & 0.02 & 0 & 0.02 & 0.01 & 0.03 & 0.019 & 0.02 & 0.04 & 0.02 & 0.02 \\
\hline REE & 0.1 & 0.04 & 0.04 & | 0.05 & 0.04 & 0.04 & | 0.07 & 0.084 & 0.06 & | 0.1 & 0.04 & 0.04 \\
\hline $\mathrm{F}$ & 0.29 & 0.69 & 0.39 & | 0.32 & 0.38 & 0.44 & 0.13 & 0.21 & 0.26 & 0.29 & 0.69 & 0.39 \\
\hline$\Sigma \mathrm{Ti}^{*}$ & 4.0 & 4.1 & 4.09 & | 4.1 & 3.9 & 4.0 & 4.0 & 4.0 & 4.0 & 4.0 & 4.1 & 4.1 \\
\hline \multirow[t]{3}{*}{$\Sigma \mathrm{Ca} *$} & 3.9 & 3.9 & 4.0 & 3.9 & 3.9 & 3.9 & \begin{tabular}{|l|}
$\mid$ \\
\end{tabular} & 4.0 & 3.9 & 3.9 & 3.9 & 4.0 \\
\hline & \multicolumn{3}{|c|}{ AW3218 } & \multicolumn{2}{|c|}{ I } & & \multicolumn{2}{|l|}{ ET336 } & & \multicolumn{3}{|c|}{ ADW304 } \\
\hline & A4p 2 & A4p3 & A2p2 & A2p3 & & A3p6 & A4p3 & A4p6 & & | A2p6 & A3p6 & A3p9 \\
\hline $\mathrm{SiO}_{2}$ & 29.5 & 29.1 & 29.5 & 29.0 & & 30.7 & 30.6 & 30.48 & & | 30.3 & 29.8 & 30.6 \\
\hline $\mathrm{Al}_{2} \mathrm{O}_{3}$ & 0.97 & 0.97 & 2.45 & 2.55 & & 1.12 & 0.82 & 1.08 & & | 2.37 & 2.3 & 3.14 \\
\hline $\mathrm{TiO}_{2}$ & 33.4 & 31 & 31.5 & 31.8 & & 37.1 & 37.6 & 37.03 & & | 35.2 & 35.4 & 33.0 \\
\hline $\mathrm{FeO}$ & 4.72 & 5.24 & 2.88 & 2.86 & & 2.1 & 2.03 & 1.82 & & | 1.59 & 1.71 & 1.94 \\
\hline $\mathrm{CaO}$ & 26.1 & 25.3 & 24.5 & 25.1 & & 27.5 & 27.1 & 26.98 & & | 27.3 & 27.4 & 27.5 \\
\hline $\mathrm{Nb}_{2} \mathrm{O}_{5}$ & 1.63 & 1.59 & 4.14 & 4.94 & & 0.49 & 0.59 & 0.46 & & | 0.65 & 0.34 & 0.44 \\
\hline $\mathrm{La}_{2} \mathrm{O}_{3}$ & 0.35 & 1.14 & 1 & 0.90 & & 0.48 & 0.45 & 0.69 & & 0.57 & 0.61 & 1.06 \\
\hline $\mathrm{Ce}_{2} \mathrm{O}_{3}$ & 1.76 & 2.07 & 2.07 & 0.76 & & 0.31 & 0.52 & 0.87 & & | 0.81 & 0.81 & 0.53 \\
\hline \multicolumn{2}{|l|}{$\mathrm{Nd}_{2} \mathrm{O}_{3}$} & 1.13 & & 0.23 & & & & & & I & & \\
\hline $\mathrm{F}$ & 1.57 & 2.4 & 1.98 & 1.89 & & 0.23 & 0.26 & 0.54 & & | 1.2 & 1.58 & 1.68 \\
\hline \multicolumn{2}{|c|}{ ion/4 Si } & & & & I & & & & & & & \\
\hline $\mathrm{Si}$ & 4.0 & 4.0 & 4.0 & 4.0 & & 4.0 & 4.0 & 4.0 & & 4.0 & 4.0 & 4.0 \\
\hline $\mathrm{Al}$ & 0.15 & 0.16 & 0.39 & 0.41 & & 0.17 & 0.13 & 0.167 & & | 0.37 & 0.36 & 0.48 \\
\hline $\mathrm{Ti}$ & 3.4 & 3.2 & 3.2 & 3.3 & & 3.6 & 3.7 & 3.7 & & | 3.5 & 3.6 & 3.2 \\
\hline $\mathrm{Fe}$ & 0.53 & 0.6 & 0.33 & 0.33 & & 0.23 & 0.22 & 0.2 & & 0.18 & 0.19 & 0.21 \\
\hline $\mathrm{Ca}$ & 3.8 & 3.7 & 3.6 & 3.7 & & 3.8 & 3.8 & 3.8 & & | 3.9 & 3.9 & 3.9 \\
\hline $\mathrm{Nb}$ & 0.10 & 0.10 & 0.25 & 0.31 & & 0.03 & 0.03 & 0.027 & & 0.04 & 0.02 & 0.03 \\
\hline REE & 0.10 & 0.22 & 0.15 & 0.1 & & 0.04 & 0.05 & 0.075 & & | 0.07 & 0.07 & 0.08 \\
\hline $\mathrm{F}$ & 0.67 & 1.0 & 0.85 & 0.82 & & 0.09 & 0.11 & 0.224 & & | 0.5 & 0.67 & 0.69 \\
\hline$\Sigma \mathrm{Ti}^{*}$ & 4.1 & 4.0 & 3.9 & 4.0 & & 4.0 & 4.0 & 4.0 & & 4.0 & 4.1 & 3.9 \\
\hline$\Sigma \mathrm{Ca}^{*}$ & 4.0 & 4.0 & 4.0 & 4.1 & & 3.9 & 3.9 & 3.896 & & 4.0 & 4.0 & 4.0 \\
\hline \multicolumn{5}{|c|}{$\Sigma \mathrm{Ti}^{*}=$ total cations in the $\mathrm{Ti}$ site } & \multicolumn{5}{|c|}{$\Sigma \mathrm{Ca}^{*}=$ total cations in the Ca site } & & & \\
\hline
\end{tabular}

